\title{
33. MINERAL CHEMISTRY OF VOLCANIC SEQUENCES FROM HOLE 917A, SOUTHEAST GREENLAND MARGIN ${ }^{1}$
}

\author{
Alain Demant ${ }^{2}$
}

\begin{abstract}
During Ocean Drilling Program Leg 152, a 779-m-thick volcanic sequence was drilled at Hole 917A, on the feather edge of the seaward-dipping reflector sequence. The volcanic succession, which erupted under subaerial conditions, was subdivided into three series (Upper, Middle, and Lower) and 92 flow units. The Upper Series comprises picrites and olivine-phyric basalts. The Middle Series basalts are more evolved, and dacitic lavas and tuffs were erupted at the base of this series. Lavas from the Lower Series show a wider compositional range. A detailed mineralogical study of the different petrographical types shows that olivine is the principal phenocryst phase in the basalts, whereas clinopyroxene and plagioclase are the main components of the groundmass. High-Mg olivines (up to $\mathrm{Fo}_{92.4}$ ) with chrome-spinel inclusions are abundant in the picrites and olivine-phyric basalts. Fo-content of the olivine decreases as a function of the composition of the whole rock except in some aphyric basalts with ophitic textures where the olivine underwent further re-equilibration during cooling. Plagioclase exhibits a large compositional range from bytownite $\left(\mathrm{An}_{91}\right)$ in the more primitive basalts to oligoclase $\left(\mathrm{An}_{21}\right)$ for the late crystallizing feldspar in the ophitic textures. Plagioclases from the Upper Series lavas are very poor in $\mathrm{K}_{2} \mathrm{O}$. The presence of bytownite phenocrysts $\left(\mathrm{An}_{86-}\right.$ ${ }_{66}$ ) associated with sodic sieve-textured plagioclase $\left(\mathrm{An}_{36-26}\right)$ in the dacite (Unit 54) clearly demonstrates that this lava is a mixed lava. Pyroxenes are mainly clinopyroxene, but pigeonite and orthopyroxene were found in the matrix of some differentiated basalts with ophitic textures. The low Ti contents of the pyroxenes and the evolution trends are typical of tholeiitic lavas. The development of sector zoning in pyroxene microphenocrysts of the more differentiated basalts has a scattering effect on the distribution of the points on the pyroxene quadrilateral. Opaque oxides crystallize late and are mainly titanomagnetite. Ilmenite is also present in some lavas.

The volcanic succession drilled at Hole 917A presents many petrographical and mineralogical similarities to the flood basalts of the Scoresby Sund region in East Greenland. These thick basaltic sequences, which characterize the North Atlantic volcanic rifted margins, were emplaced during a short time interval during the phase of continental breakup. The Lower and Middle Series have evolved in crustal magma chambers. The frequency of picrites in the Upper Series emphasizes an easier access of more primitive magmas to the surface during the final phase of rifting.
\end{abstract}

\section{INTRODUCTION}

One of the major goals of Leg 152 was to drill the seaward-dipping reflector sequence (SDRS) of the East Greenland rifted margin, formed during the initial breakup of the Northeast Atlantic. The volcanic nature of the SDRS was established by Deep Sea Drilling Project Leg 81 (Rockall Plateau), and Ocean Drilling Program Leg 104 (Vøring Plateau) on the European margin (Roberts et al., 1985; Eldholm, Thiede, Taylor, et al., 1989). During Leg 152, six sites (914-919) were drilled along a transect close to $63^{\circ} \mathrm{N}$ (Fig. 1). Hole $917 \mathrm{~A}$, located on the shelf approximately $50 \mathrm{~km}$ from the coast of southeast Greenland, penetrated the entire early Tertiary volcanic sequence $(779 \mathrm{~m})$ and reached the pre-volcanic basement.

Hole 917A had an overall high core recovery of $55.7 \%$ for the volcanic section. On the basis of visual cores inspection, 92 flow units were distinguished and classified into nine petrographical types. The volcanic succession was subdivided into three series: Upper $(141.5 \mathrm{~m}$ thick), Middle (193.4 m thick), and Lower (444 m thick). This subdivision is supported by the stratigraphic compositional variation of $\mathrm{Ni}$ and Ba/Zr (Larsen, Saunders, Clift, et al., 1994; Fitton et al., 1995). The boundary between the Upper and Middle Series corresponds to a 67-cm sandstone horizon (Unit 34A) at 183.4 meters below seafloor (mbsf), while the beginning of the Middle Series, at $376.7 \mathrm{mbsf}$, is marked by the eruption of dacitic lavas (Units 57, 55, and 54) and welded tuff (Unit 56). The entire volcanic succession has been erupted under subaerial conditions as revealed by the presence of oxidized

${ }^{1}$ Saunders, A.D., Larsen, H.C., and Wise, S.W., Jr. (Eds.), 1998. Proc. ODP, Sci. Results, 152: College Station, TX (Ocean Drilling Program).

${ }^{2}$ Laboratoire de Pétrologie Magmatique, URA CNRS 1277 and FU 17, CEREGE BP 80, 13545 Aix-en-Provence, Cedex 04, France. ADEMANT@ ARBOIS.CEREGE.FR scoriaceous flow tops or red horizons between some flows. However, Units 52/53 and 92 have brecciated glassy bases, indicating an emplacement in a wet environment. The absence of volcaniclastic sediments interlayered with the lava flows is a major difference with the section drilled in the SDRS north of the Vøring Plateau (Parson et al., 1989; Vierek et al., 1989). ${ }^{40} \mathrm{Ar} /{ }^{\beta 9} \mathrm{Ar}$ dating has given a Paleogene age (around 60 m.y.) for the Lower and Middle Series and a short time interval of about $2 \mathrm{~m}$.y. for the emplacement of this 650-m-thick lava pile (Sinton and Duncan, this volume), implying a relatively high volcanic production rate for the SDRS.

The Formation MicroScanner (FMS) logging tool, which was deployed successfully in Hole 917A, provided continuous data of good quality in the interval from 595 to 165 mbsf. The natural gamma-ray tool also proved to be useful to determine the limits between flow units of different chemical compositions. Both the FMS and gammaray data were used to establish a new lithostratigraphic log and to determine the morphology and exact thickness of each flow unit in this interval (Demant et al., 1995; Cambray, this volume). The discrepancies with the lithostratigraphic log established on board are relatively limited and mainly concern the dacitic sequence at the base of Unit 52 (327-380 mbsf), which corresponds to the worst core recovery. For better correlation with the geochemical studies, the lithologic unit numbers used in the text are those of the initial report (Larsen, Saunders, Clift, et al., 1994).

This study is concerned with the petrography and igneous mineral chemistry of the different rock types defined at Hole 917A. The analogies with the lower Tertiary plateau basalts of the Scoresby Sund region, East Greenland, are briefly commented. These data, in connection with the geochemical studies presented in this volume, contribute to characterize the intense volcanism that accompanied the rifting of the continental margin during the early opening of the North Atlantic Ocean. The mineral chemistry of the secondary phases (zeo- 
Figure 1. Map of the northeast Atlantic showing the location of Hole 917A and other DSDP and ODP drill sites from the Reykjanes Ridge and the Rockall and Vøring Plateaus (from Larsen, Saunders, Clift, et al., 1994). KR = Knipovich Ridge, GFZ = Greenland Fracture Zone, SFZ = Senja Fracture Zone, JMFZ = Jan Mayen Fracture Zone, JMR = Jan Mayen Ridge, GIR $=$ Greenland - Iceland Ridge, and FIR $=$ Faeroes Iceland Ridge.

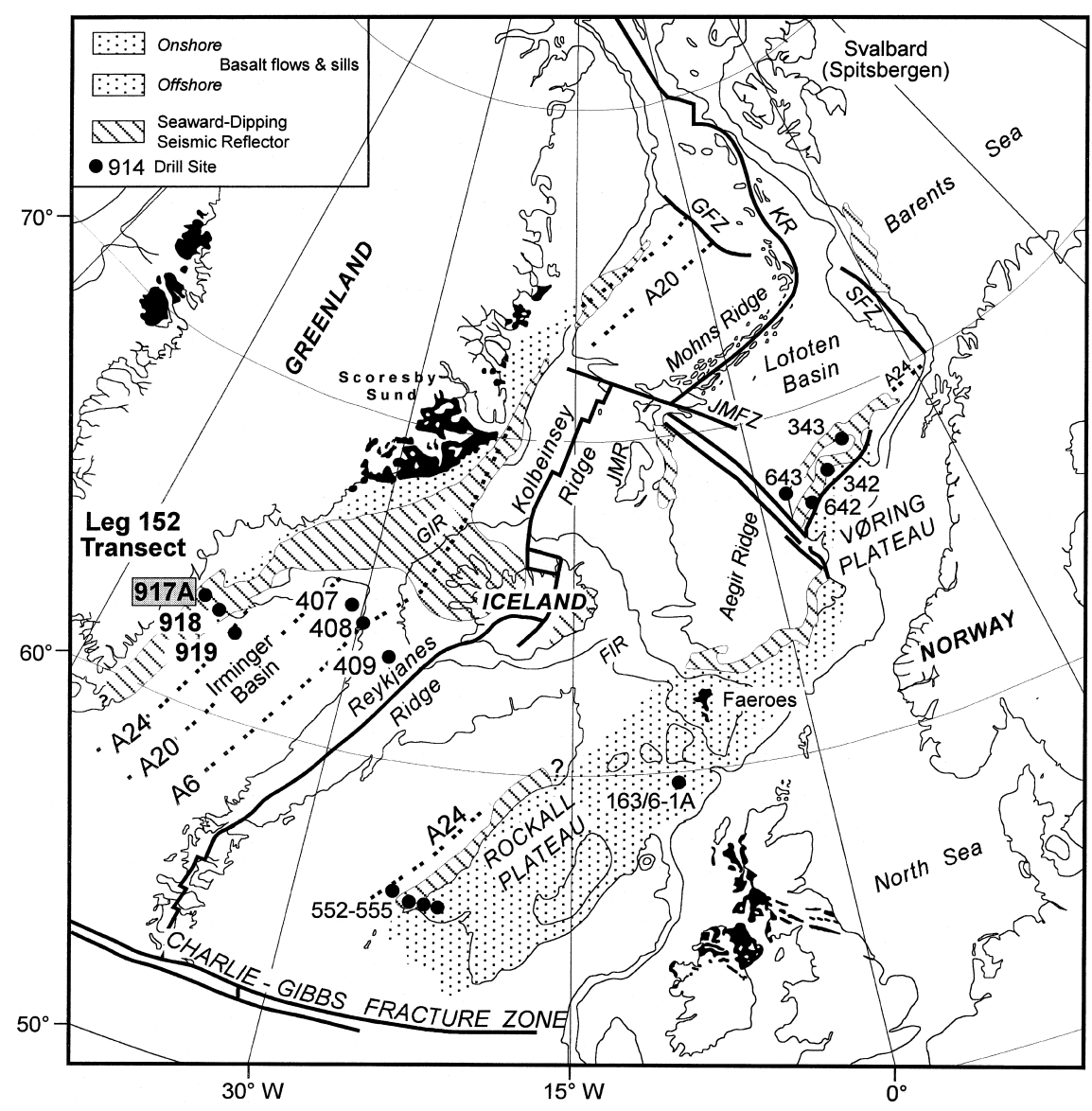

lites and clays) is presented in a companion paper (Demant et al., this volume).

\section{PETROGRAPHY}

Rock types were defined by visual core descriptions and thin section studies. Sixty-six flow units were examined on board and 68 new samples were examined during shore-based studies. Modal compositions were determined on 45 samples (Table 1). The Upper Series lavas are predominantly picrites and olivine-phyric basalts, with intercalation of less primitive aphyric olivine basalts. Basalts from the Middle Series are more evolved (nickel content $<80 \mathrm{ppm}$ ) and correspond to pale-colored aphyric or plagioclase-phyric basalts. Dacitic lava flows and acidic tuffs are present near the base of this Middle Series, and a tuffaceous level (Unit 35B) was observed near the top. Lavas of the Lower Series show a wider range of composition with alternating primitive lavas (picrites and olivine-phyric basalts) and more differentiated basalts (refer to the stratigraphic log in Larsen, Saunders, Clift, et al., 1994). The characteristics of the different petrological types are briefly summarized below and their modal compositions reported in Table 1 . The textures are defined according to the terms used by MacKenzie et al. (1982).

The picrites are porphyritic rocks containing abundant olivine phenocrysts with frequent elongated platy shape and with chromite inclusions. Olivine varies in size continuously from 2 to $0.2 \mathrm{~mm}$, and is always subhedral to euhedral; all of the olivines were therefore counted as phenocrysts. Modal olivine percentages range from $25 \%$ to $50 \%$ (Table 1). The matrix is generally subophitic and composed of clinopyroxene enclosing plagioclase laths. Unit 61B picrite (Lower Series) is slightly different; olivine phenocrysts are more equant, and plagioclase, in some cases, is assembled as glomerocrysts. Glass is never very abundant in the picrites $(<6 \%)$ and is restricted to wedge-shaped interstices between plagioclase laths. Unit 16, which contains $27.8 \%$ of olivine phenocrysts to microphenocrysts (Table 1) and $718 \mathrm{ppm} \mathrm{Ni}$, is redefined as a picrite instead of aphyric olivine basalt as first supposed on board.

In the olivine-phyric basalts, euhedral to subhedral olivine phenocrysts, $3-0.5 \mathrm{~mm}$ in size, are easily recognizable in hand specimens; microphenocrysts, $0.5-0.2 \mathrm{~mm}$ in size, are also present. These rocks differ from the picrites in having less modal total olivine (15\%$22 \%$; Table 1). The textures are mostly intersertal and have a subophitic tendency. Chlorite and zeolites are abundant in the matrix. Unit 33 was defined on board as an olivine-phyric basalt; nonetheless, because it contains less than $1 \%$ olivine phenocrysts and plagioclase glomerocrysts, it is more akin to the aphyric olivine basalt petrological type (Table 1). The low $\mathrm{Mg}$ number of the whole rock $(\mathrm{Mg}$ number is here defined as the molar ratio: $100 \times \mathrm{Mg} /[\mathrm{Mg}+0.85 \times$ total $\mathrm{Fe}]$ ), which was calculated from the data of Fitton et al. (Chap. 28, this volume), supports this statement.

The aphyric olivine basalts contain only scarce olivine phenocrysts ( $>0.5 \mathrm{~mm}$ in size); total modal percentages of olivine (including microphenocrysts), however, reach $5 \%-16 \%$. The groundmass is fine grained with intersertal to intergranular textures, but perfect ophitic textures are well represented in the Lower Series (Units 84, 87,89 , and 90) with clinopyroxene oikocryst, up to $5 \mathrm{~mm}$ in diameter, enclosing numerous tabular plagioclases.

The olivine-plagioclase-phyric basalts are mostly seriate textured. They contain $4 \%-6 \%$ olivine phenocrysts and $1 \%-5 \%$ plagioclase phenocrysts in a groundmass composed of clinopyroxene, plagioclase and oxide opaque minerals.

The olivine-plagioclase-clinopyroxene-phyric basalts are slightly more differentiated. Olivine phenocrysts or microphenocrysts have modal percentages of less than $10 \%$. Plagioclase phenocrysts are 
Table 1. Modal compositions of representative samples of the different petrological types.

\begin{tabular}{|c|c|c|c|c|c|c|c|c|c|c|c|c|c|c|}
\hline \multirow{2}{*}{$\begin{array}{l}\text { Core, section, } \\
\text { interval }(\mathrm{cm})\end{array}$} & \multirow[b]{2}{*}{ Piece } & \multirow[b]{2}{*}{ Unit } & \multirow[b]{2}{*}{ Rock type } & \multirow[b]{2}{*}{ Texture } & \multicolumn{5}{|c|}{ Phenocrysts } & \multicolumn{5}{|c|}{ Groundmass } \\
\hline & & & & & $\mathrm{Ol}$ & Cpx & $\mathrm{Pl}$ & Op & $\mathrm{Qz}$ & $\mathrm{Ol}$ & Cpx & $\mathrm{Pl}$ & Op & Glass \\
\hline $\begin{array}{l}\text { 152-917A- } \\
\text { 13R-2, 70-75 } \\
\text { 16R-4, 64-65 } \\
\text { 18R-3, 35-36 } \\
\text { 20R-4, 122-127 } \\
\text { 57R-3, 85-86 }\end{array}$ & $\begin{array}{c}1 \mathrm{C} \\
8 \mathrm{~A} \\
1 \\
10 \\
1\end{array}$ & $\begin{array}{l}16 \\
21 \\
25 \\
32 \mathrm{~B} \\
61 \mathrm{~B}\end{array}$ & $\begin{array}{l}\text { picrite } \\
\text { picrite } \\
\text { picrite } \\
\text { picrite } \\
\text { picrite }\end{array}$ & $\begin{array}{l}\text { subophitic } \\
\text { subophitic } \\
\text { subophitic } \\
\text { subophitic } \\
\text { subophitic }\end{array}$ & $\begin{array}{l}27.8 \\
49.6 \\
25.3 \\
43.4 \\
34.6\end{array}$ & & 1 & & & & $\begin{array}{l}30.1 \\
20.5 \\
28.3 \\
24.4 \\
18.4\end{array}$ & $\begin{array}{l}39.5 \\
25.7 \\
34.8 \\
25.1 \\
44.8\end{array}$ & $\begin{array}{l}1.6 \\
4.2 \\
5.8 \\
1.2 \\
1.2\end{array}$ & $\begin{array}{l}1 \\
5.8 \\
6\end{array}$ \\
\hline $\begin{array}{l}18 \mathrm{R}-4,99-100 \\
18 \mathrm{R}-6,101-102 \\
19 \mathrm{R}-2,40-41 \\
19 \mathrm{R}-4,48-49 \\
72 \mathrm{R}-1,82-85 \\
101 \mathrm{R}-4,85-86\end{array}$ & $\begin{array}{l}7 \mathrm{~A} \\
5 \mathrm{~A} \\
1 \mathrm{~B} \\
2 \mathrm{~B} \\
3 \mathrm{D} \\
5\end{array}$ & $\begin{array}{l}26 \\
27 \\
30 \\
31 \mathrm{~A} \\
73 \mathrm{~A} \\
92\end{array}$ & $\begin{array}{l}\text { ol phyric b } \\
\text { ol phyric b } \\
\text { ol phyric b } \\
\text { ol phyric b } \\
\text { ol phyric b } \\
\text { ol phyric b }\end{array}$ & $\begin{array}{l}\text { intersertal } \\
\text { intersertal } \\
\text { intersertal } \\
\text { subophitic } \\
\text { subophitic } \\
\text { intersertal }\end{array}$ & $\begin{array}{l}15 \\
20.5 \\
10 \\
17 \\
7.3 \\
8.6\end{array}$ & & & & & $\begin{array}{r}12 \\
9.6 \\
10.4\end{array}$ & $\begin{array}{l}27 \\
27.5 \\
24.7 \\
35 \\
31.3 \\
24\end{array}$ & $\begin{array}{l}43.6 \\
38.5 \\
37.7 \\
45 \\
46.8 \\
39\end{array}$ & $\begin{array}{l}4 \\
3 \\
3.4 \\
3 \\
1.7 \\
3\end{array}$ & $\begin{array}{r}10.4 \\
10.5 \\
12.2 \\
\\
3.3 \\
15\end{array}$ \\
\hline $\begin{array}{l}14 \mathrm{R}-4,82-83 \\
15 \mathrm{R}-2,6-7 \\
16 \mathrm{R}-1,9-10 \\
16 \mathrm{R}-6,75-76 \\
17 \mathrm{R}-2,74-75 \\
17 \mathrm{R}-4,72-78 \\
21 \mathrm{R}-3,142-143 \\
78 \mathrm{R}-2,135-136 \\
80 \mathrm{R}-4,101-102 \\
83 \mathrm{R}-3,16-17 \\
88 \mathrm{R}-7,83-86 \\
94 \mathrm{R}-1,71-74 \\
99 \mathrm{R}-2,73-74\end{array}$ & $\begin{array}{l}2 \mathrm{~A} \\
1 \mathrm{~A} \\
2 \mathrm{~A} \\
5 \\
2 \\
3 \mathrm{~B} \\
5 \\
4 \mathrm{~B} \\
1 \mathrm{D} \\
1 \mathrm{~B} \\
1 \mathrm{C} \\
1 \mathrm{C} \\
1 \mathrm{~F}\end{array}$ & $\begin{array}{l}18 \\
19 \\
20 \\
22 \\
23 \\
24 \\
33 \\
76 \\
79 \\
82 \\
84 \\
87 \\
90\end{array}$ & $\begin{array}{l}\text { aphyric ol b } \\
\text { aphyric ol b } \\
\text { aphyric ol b } \\
\text { aphyric ol b } \\
\text { aphyric ol b } \\
\text { aphyric ol b } \\
\text { aphyric ol b } \\
\text { aphyric ol b } \\
\text { aphyric ol b } \\
\text { aphyric ol b } \\
\text { aphyric ol b } \\
\text { aphyric ol b } \\
\text { aphyric ol b }\end{array}$ & $\begin{array}{l}\text { intersertal } \\
\text { intergranular } \\
\text { intergranular } \\
\text { intersertal } \\
\text { intergranular } \\
\text { intergranular } \\
\text { intersertal } \\
\text { subophitic } \\
\text { subophitic } \\
\text { intersertal } \\
\text { ophitic } \\
\text { ophitic } \\
\text { intersertal }\end{array}$ & $\begin{array}{r}1 \\
<1\end{array}$ & $\begin{array}{l}<1 \\
<1\end{array}$ & & & & $\begin{array}{r}5 \\
5 \\
2 \\
10 \\
5 \\
5 \\
5 \\
15 \\
10 \\
9.8 \\
9.6 \\
16.5 \\
10\end{array}$ & $\begin{array}{l}40 \\
42 \\
52 \\
25 \\
40 \\
40 \\
39 \\
35 \\
30 \\
27.6 \\
31.5 \\
24.4 \\
25\end{array}$ & $\begin{array}{l}42 \\
47 \\
40 \\
50 \\
50 \\
49 \\
45 \\
48 \\
57 \\
48.8 \\
57.6 \\
54.6 \\
45\end{array}$ & $\begin{array}{l}3 \\
5 \\
6 \\
5 \\
5 \\
5 \\
5 \\
2 \\
3 \\
3.8 \\
1.3 \\
3.2 \\
5\end{array}$ & $\begin{array}{c}10 \\
1.3 \\
15\end{array}$ \\
\hline $\begin{array}{l}84 \mathrm{R}-2,100-101 \\
90 \mathrm{R}-1,58-59 \\
90 \mathrm{R}-6,104-107\end{array}$ & $\begin{array}{l}3 \mathrm{~B} \\
2 \mathrm{~B} \\
5\end{array}$ & $\begin{array}{l}83 \\
85 \\
86\end{array}$ & $\begin{array}{l}\text { ol pl phyric b } \\
\text { ol pl phyric b } \\
\text { ol pl phyric b }\end{array}$ & $\begin{array}{l}\text { seriate } \\
\text { intersertal } \\
\text { intergranular }\end{array}$ & $\begin{array}{l}4 \\
6.3 \\
4\end{array}$ & $\begin{array}{r}5 \\
<1 \\
1.5\end{array}$ & & & & $\begin{array}{l}12 \\
12.4\end{array}$ & $\begin{array}{l}25.3 \\
27.5\end{array}$ & $\begin{array}{l}50.1 \\
50.7\end{array}$ & 3.9 & $\begin{array}{l}91 \\
6.3\end{array}$ \\
\hline $\begin{array}{l}54 \mathrm{R}-5,48-49 \\
55 \mathrm{R}-4,10-11 \\
67 \mathrm{R}-3,130-132\end{array}$ & $\begin{array}{l}1 \mathrm{~B} \\
1 \mathrm{~B} \\
6 \mathrm{~B}\end{array}$ & $\begin{array}{l}58 \\
60 \\
70\end{array}$ & $\begin{array}{l}\text { ol pl cpx phyric b } \\
\text { ol pl cpx phyric b } \\
\text { ol pl cpx phyric b }\end{array}$ & $\begin{array}{l}\text { intergranular } \\
\text { intersertal } \\
\text { intersertal }\end{array}$ & $\begin{array}{l}1 \\
8.8 \\
0.3\end{array}$ & $\begin{array}{l}0.6 \\
0.6 \\
0.8\end{array}$ & $\begin{array}{r}6 \\
12.8 \\
4.6\end{array}$ & & & $\begin{array}{l}5 \\
4\end{array}$ & $\begin{array}{l}28 \\
33\end{array}$ & $\begin{array}{l}56.4 \\
43.1\end{array}$ & $\begin{array}{l}3 \\
2.6\end{array}$ & $\begin{array}{l}77.8 \\
11.6\end{array}$ \\
\hline $\begin{array}{l}25 \mathrm{R}-1,81-82 \\
26 \mathrm{R}-2,7-8 \\
27 \mathrm{R}-2,48-49 \\
\text { 30R-1, 115-116 }\end{array}$ & $\begin{array}{l}9 \mathrm{~A} \\
1 \\
5 \\
15\end{array}$ & $\begin{array}{l}36 \\
38 \\
41 \\
43\end{array}$ & $\begin{array}{l}\text { pl phyric b } \\
\text { pl phyric b } \\
\text { pl phyric b } \\
\text { pl phyric b }\end{array}$ & $\begin{array}{l}\text { intersertal } \\
\text { intersertal } \\
\text { intersertal } \\
\text { intersertal }\end{array}$ & & $\begin{array}{l}<1 \\
<1\end{array}$ & $\begin{array}{r}<1 \\
<1 \\
1 \\
1\end{array}$ & & & & $\begin{array}{l}35 \\
25 \\
25\end{array}$ & $\begin{array}{l}45 \\
40 \\
30 \\
37\end{array}$ & $\begin{array}{r}5 \\
5 \\
10 \\
7\end{array}$ & $\begin{array}{l}15 \\
30 \\
59 \\
30\end{array}$ \\
\hline $\begin{array}{l}27 \mathrm{R}-1,2-3 \\
30 \mathrm{R}-3,36-37 \\
31 \mathrm{R}-1,148-150 \\
31 \mathrm{R}-3,110-111 \\
32 \mathrm{R}-3,137-138 \\
40 \mathrm{R}-4,78-81 \\
73 \mathrm{R}-1,129-132\end{array}$ & $\begin{array}{c}1 \\
6 \\
18 \mathrm{~B} \\
11 \mathrm{~A} \\
13 \\
6 \\
6 \mathrm{C}\end{array}$ & $\begin{array}{l}39 \\
44 \\
45 \\
46 \\
47 \\
52 \\
74 \mathrm{~A}\end{array}$ & $\begin{array}{l}\text { aphyric b (dike) } \\
\text { aphyric b } \\
\text { aphyric b } \\
\text { aphyric b } \\
\text { aphyric b } \\
\text { aphyric b } \\
\text { aphyric b }\end{array}$ & $\begin{array}{l}\text { intersertal } \\
\text { intersertal } \\
\text { intersertal } \\
\text { intersertal } \\
\text { intersertal } \\
\text { intersertal } \\
\text { hyalopilitic }\end{array}$ & $<1$ & $\begin{array}{l}<1 \\
<1\end{array}$ & $<1$ & & & 4.6 & $\begin{array}{l}46.9 \\
15 \\
10 \\
25 \\
10 \\
38\end{array}$ & $\begin{array}{l}30.5 \\
30 \\
25 \\
40 \\
25 \\
48.8 \\
20\end{array}$ & $\begin{array}{l}4.6 \\
5 \\
5 \\
5 \\
5 \\
3.7\end{array}$ & $\begin{array}{l}18 \\
50 \\
60 \\
30 \\
60 \\
4.9 \\
80\end{array}$ \\
\hline $\begin{array}{l}23 \mathrm{R}-3,10-13 \\
47 \mathrm{R}-2,70-72 \\
53 \mathrm{R}-1,77-78\end{array}$ & $\begin{array}{l}1 \mathrm{~A} \\
7 \mathrm{~B} \\
1 \mathrm{D}\end{array}$ & $\begin{array}{l}35 \mathrm{~B} \\
54 \\
56\end{array}$ & $\begin{array}{l}\text { hyaloclastite } \\
\text { dacite } \\
\text { ignimbrite }\end{array}$ & $\begin{array}{l}\text { hyalopilitic } \\
\text { hyalopilitic } \\
\text { eutaxitic }\end{array}$ & $<1$ & $\begin{array}{l}5 \\
4 \\
0.4\end{array}$ & $\begin{array}{r}26 \\
6 \\
2\end{array}$ & 4.4 & $\begin{array}{c}<1 \\
0.2\end{array}$ & & & & & $\begin{array}{l}64.6 \\
90 \\
97.4\end{array}$ \\
\hline
\end{tabular}

Notes: Modal compositions were determined counting 1500 or 2000 points. Abbreviations: $\mathrm{b}=$ basalt, $\mathrm{pl}=$ plagioclase, $\mathrm{ol}=$ olivine, $\mathrm{cpx}=$ clinopyroxene, op $=$ opaques, and qz $=$ quartz.

more abundant than in the olivine-plagioclase-phyric basalts $(4.6 \%-$ $12.8 \%$ ), and they are frequently clustered in aggregates. Clinopyroxene is not a major phenocryst phase $(<1 \%)$ but it is present as microphenocrysts. Unit 60 has an intersertal texture with $77.8 \%$ glass.

The plagioclase-phyric basalts do not contain abundant plagioclase phenocrysts (around 1\%), but they are visible in hand specimens. These crystals present frequent disequilibrium textures. Olivine is totally absent, even as microphenocrysts, and clinopyroxene is very rare as microphenocrysts. The intersertal groundmass is fine grained and composed of clinopyroxene, plagioclase, and opaque minerals.

The aphyric basalts are not very different from the plagioclasephyric basalts. They are characterized by the presence of very few plagioclase or clinopyroxene microphenocrysts set in a fine-grained matrix made of plagioclase laths, small clinopyroxene grains, and opaque minerals. Nevertheless, devitrified glass is more abundant here than it is in the plagioclase-phyric basalts.

The dacites and tuffs are present only in the Middle Series. Unit $35 \mathrm{~B}$ is a porphyritic tuff that contains $25 \%$ fresh plagioclase crystals along with minor clinopyroxene and oxides. This unit was dated at 61.7 m.y. by Sinton and Duncan (this volume). The welded ash flow tuff, Unit 56, has an eutaxitic texture, is highly oxidized, and contains $2 \%$ plagioclase phenocrysts, rare clinopyroxenes, and rounded quartz. The dacitic lava (Unit 54) is more porphyritic (10\% pheno- crysts) but most of the phenocrysts are plagioclase-pyroxene clots that seem to correspond to basaltic clasts. This rock is a complex mixture of a glassy acidic liquid and deep-brown quenched basaltic fragments with crenulated margins, and contains some rounded quartz and sieve-textured plagioclases. The glassy acidic liquid is devitrified into spherulitic structures (up to 3-mm diameter). These spherulites often contain a vesicle at the core filled with brown clays or heulandite-type zeolites (Demant et al., this volume). Tridymite nests are present on the margin of the vesicle and in the devitrified glass. The matrix between the spherulites has a brownish color and corresponds to hydrated glass. Irregularly shaped, elongated vesicles filled with zeolites are abundant (5\%) throughout this rock.

\section{MINERAL CHEMISTRY Analytical Methods}

The igneous mineralogy was determined on 32 polished thin sections that were selected from the 68 studied samples and covered all of the petrographic types. The minerals were analyzed on a CAMEBAX microprobe using a wavelength-dispersive spectrometer, at the Service Commun Microsonde, Université de Montpellier II. The standard operating conditions included an accelerating voltage of 15 $\mathrm{kV}$, a beam current of $10 \mathrm{nA}$, and counting times of 6-20 s depending 
on the analyzed elements. A special program, analyzing the alkalies first, was employed for feldspars. A new accurate computer correction program (Merlet, 1994) was used to calculate the elemental concentrations. The microprobe analyses are available on the CD-ROM in the back pocket of this volume, but representative analyses are given in Tables 2-7 at the end of this chapter.

\section{Olivine}

Olivine, or its replacement products, are present in all of the basalts except the most differentiated ones (i.e., the plagioclase-phyric and aphyric basalts). Olivines range in size from obvious phenocrysts through microphenocrysts. In the aphyric olivine basalts it is present only as groundmass-size crystals. Olivines are frequently altered and pseudomorphed by brown or green clay minerals. This alteration preserves, when present, an earlier oxidation rim of opaque minerals. Six units, most of them from the Lower Series, corresponding to four petrographic types, contain unaltered olivines.

The microprobe analyses (Table 2) show a good correlation between olivine compositions and the chemistry of the rocks (Fitton et al., Chap. 28, this volume), illustrated by the Mg numbers. Fo contents of the phenocrysts progressively decrease from the picrites to the aphyric olivine basalts (Fig. 2). Nevertheless, the olivine-plagioclase-clinopyroxene-phyric basalt of Unit 60 , which is slightly more evolved $(\mathrm{Mg}$ number $=61.97)$ than the aphyric basalts of Units 84 and 87 (66.79 and 64.45, respectively), has olivine with higher Forsterite (Fo) content. This point will be further discussed in the paper.

Olivine compositions of up to $\mathrm{Fo}_{92.4}$ were obtained in Unit 32B picrite (Table 2). Megacrysts of residual character are frequent in olivine-rich magmas (Albarède and Tamagnan, 1988). Even euhedral olivine crystals can be xenocrysts that resulted from a double process of corrosion and overgrowth during rapid temperature drop, as indicated by experimental studies (Boudier, 1991). However, the highmagnesium olivines of Unit 32B do not seem to correspond to xenocrysts as their $\mathrm{Mg}$-contents are in agreement with the calculated equilibrium olivine composition ( $\mathrm{Fo}_{93.9}$; L. Larsen, pers. comm., 1995) obtained from the whole rock analysis by the T(sum) method of Ford et al. (1983). Moreover, because the calculated olivine is slightly more magnesian than the most magnesian measured olivine, this picrite $(23 \% \mathrm{MgO})$ is probably somewhat cumulitic. On the other hand, the observed compositional range of olivine correlates well with the crystal size. Large equant olivine phenocrysts are the more magnesian $\left(\mathrm{Fo}_{92.4}-\mathrm{Fo}_{90.2}\right)$; they have a homogeneous composition except for the outermost narrow rims. Elongated platy olivines are slightly less magnesian $\left(\mathrm{FO}_{90.7}-\mathrm{Fo}_{87.5}\right)$, whereas the smallest crystals have compositions ranging from $\mathrm{Fo}_{85}$ to $\mathrm{FO}_{77.5}$.

Unit $61 \mathrm{~B}$ picrite contains magnesian olivine phenocrysts (up to $\mathrm{Fo}_{90.7}$ ) whose compositions are in agreement with the calculated equilibrium olivine $\left(\mathrm{Fo}_{91.4}\right)$. The more limited compositional range $\left(\mathrm{Fo}_{90.7}-\mathrm{Fo}_{84.8}\right)$ in this sample is probably due to the fact that olivine is relatively altered, and only the cores of the larger crystals are preserved. This is also the case for Unit 73A; here again, the maximum analyzed Fo content $\left(\mathrm{Fo}_{87.4}\right)$ corresponds to the calculated value $\left(\mathrm{Fo}_{87.6}\right)$.

Aphyric olivine basalt of Unit 87 presents the larger compositional range $\left(\mathrm{Fo}_{78.8}-\mathrm{Fo}_{61.1}\right)$. However, the highest magnesium content analyzed in these olivines is much lower than the calculated equilibrium olivine $\left(\mathrm{Fo}_{86.8}\right)$. In Unit 84 , which has similar $\mathrm{Mg}$ number and calculated olivine composition, measured olivine compositions are relatively homogeneous and in the range $\mathrm{Fo}_{65.5}-\mathrm{Fo}_{61}$. In this unit, olivine crystals are very small $(0.5-0.2 \mathrm{~mm})$ and surrounded by a reddish oxidized rim. Olivine phenocrysts less magnesian than the calculated equilibrium olivine are explained, as suggested by Larsen et al. (1989), by further re-equilibration during groundmass crystallization. This is in agreement with the ophitic texture of these rocks, which indicates a slow cooling rate. In the olivine-plagioclase-clinopyroxenephyric basalt (Unit 60), measured and calculated olivine compositions are again similar (about $\mathrm{Fo}_{84}$; Fig. 2).

In conclusion, microprobe data demonstrate that most of the analyzed olivines have apparent near-equilibrium compositions except for those from the aphyric olivine basalts of Units 84 and 87, which seem to have re-equilibrated during subsolidus cooling. No xenocrystic olivines, like those observed in the lower Tertiary plateau basalts of the Scoresby Sund region, East Greenland (Larsen et al., 1989), were identified in Hole 917A basalts.

$\mathrm{Ni}$ contents in the Mg-rich olivines of the picrites are relatively high $(0.5 \%)$, but these values decrease rapidly to near the detection limit (around $0.2 \%$ ) at $\mathrm{Fo}_{85}$. $\mathrm{MnO}$ shows a negative correlation with Fo content and increases from $0.2 \%$ to $0.6 \%$ when $\mathrm{MgO}$ decreases. $\mathrm{CaO}$ lies in the range of $0.19 \%-0.36 \%$, and no systematic evolution is observed. These values are in the range of compositions for olivine phenocrysts from most basalts.

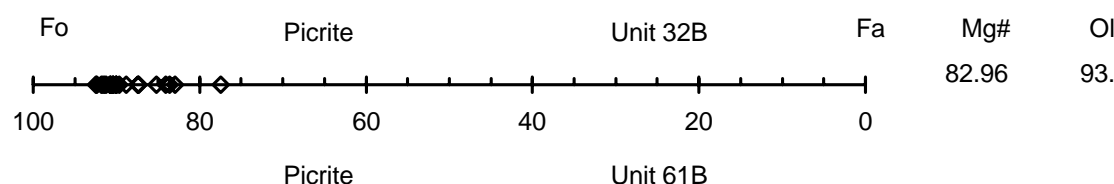

Figure 2. Olivine compositional ranges for the different petrographical types. $\mathrm{Mg}$ numbers of the whole rocks were calculated from the data of Fitton et al. (Chap. 28, this volume) and the theoretical equilibrium olivines $(\mathrm{Olc})$ by the $\mathrm{T}(\mathrm{sum})$ method of Ford et al. (1983). Solid diamonds = large phenocrysts; open diamonds $=$ smaller crystals .
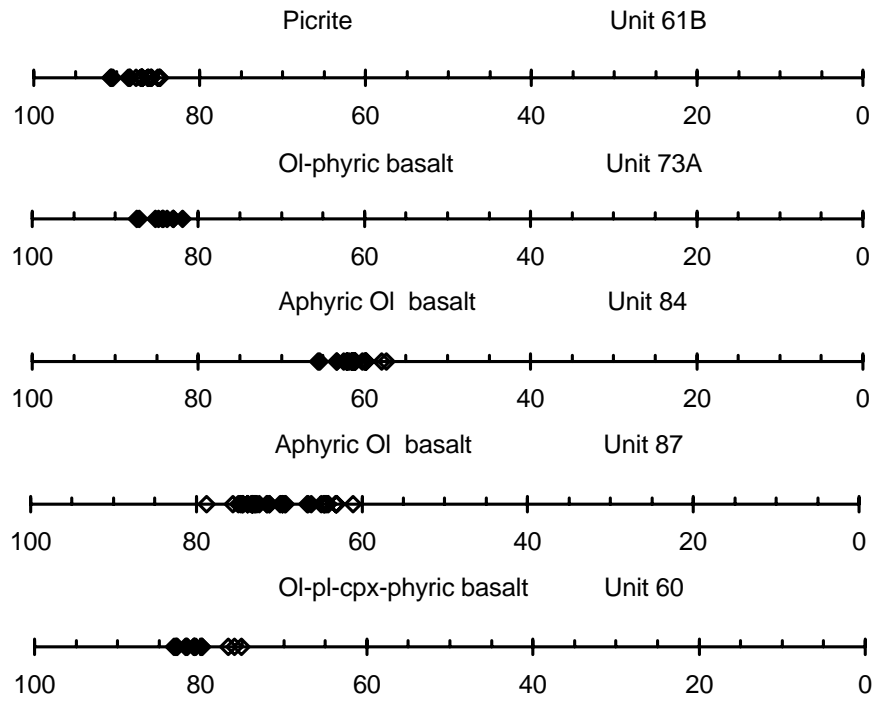


\section{Spinels}

The more magnesian rocks found in Hole 917A (i.e., the picrites and olivine-phyric basalts) contain early-formed, deep-brown crystals of spinel (s.l.) enclosed within olivine phenocrysts. Typically the spinels (s.l.) are less than $0.1 \mathrm{~mm}$ in size and vary in form from perfect octahedral crystals to more anhedral and rounded forms. No spinels were found within the groundmass. The presence of spinels in Unit 16, in accordance with the high $\mathrm{Cr}$ content of the whole rock (1428 ppm) and the abundance of olivine crystals (Table 1), confirms that this rock is really a picrite. The presence of spinel in the aphyric olivine basalt of Unit 87, and its absence from the similar aphyric olivine basalt Unit 84, coincides with a relatively high $\mathrm{Cr}$ content $(526$ $\mathrm{ppm}$ ) in Unit 87 and a lower Cr content ( $355 \mathrm{ppm}$ ) in Unit 84 (Fitton et al., Chap. 28, this volume). Therefore, spinel crystallization seems to be restricted to lavas with $\mathrm{MgO}$ above $8 \%$ and $\mathrm{Cr}$ contents higher than $500 \mathrm{ppm}$.

Toward the margins or near the fractures of the olivine crystals, spinels are opacified, suggesting a late-stage crystal-melt reaction. Spinels are not, however, affected by alteration (Allan, 1992). This is apparent from Unit 32B picrite in which spinels are preserved within olivine phenocrysts entirely replaced by saponite (Demant et al., this volume). Spinels are plotted in Figure 3, and representative analyses are shown in Table 3.

Most of the analyzed spinels are depleted in $\mathrm{Fe}^{3+}$ and can therefore be considered as close to magmatic compositions. This magmatic origin is also confirmed by a clear relationship between the $\mathrm{Mg}$ / $\left(\mathrm{Mg}+\mathrm{Fe}^{2+}\right)$ ratio of coexisting spinels and olivine. The spinels have high chromium $(30 \%-35 \%)$, aluminum $(15 \%-27 \%)$, and magnesium $(9 \%-16 \%)$ contents and can be referred to, using the multicomponent spinel prism of Irvine (1965), as chromian-spinels. The compositional variations are limited between and within units, except for Units 32B and 87, which plot in separate fields. The $\mathrm{Mg} /\left(\mathrm{Mg}+\mathrm{Fe}^{2+}\right)$ ratios are in the range of $0.6-0.4$ and the $\mathrm{Cr} /(\mathrm{Cr}+\mathrm{Al})$ ratios vary between 0.55 and 0.45 . Spinels from picrite $32 \mathrm{~B}$ have higher $\mathrm{Cr}_{2} \mathrm{O}_{3}$ (up to $45 \%$ ) and $\mathrm{MgO}$ contents (Fig. 3 ); these differences with the spinels from the other picrites show that the high $\mathrm{MgO}$ content of this lava is not only the result of olivine accumulation. Moreover, the relationship between the $\mathrm{MgO}$ content of the lavas and that of the spinels demonstrates that the high-Mg olivines that include the spinels are not xenocrysts. The composition of the spinels from Hole 917A is in the range of spinels from mid-ocean-ridge basalt, which crystallizes at a temperature of about $1200^{\circ} \mathrm{C}$ and a magmatic oxygen fugacity below the nickel/nickel oxide oxygen buffer (Allan, 1992). Chromite in the aphyric olivine basalt (Unit 87) shows higher contents of $\mathrm{Fe}^{3+}$ and $\mathrm{Ti}$, which result from partial re-equilibration of chromite crystals with the liquid during groundmass crystallization, and their progressive transformation to high-chromian titanomagnetite (28\%-20\% $\mathrm{Cr}_{2} \mathrm{O}_{3}$, but less than $5 \% \mathrm{MgO}$ and $12 \% \mathrm{Al}_{2} \mathrm{O}_{3}$ ). This reinforces the suggestion that the low $\mathrm{Mg}$ ratios of the analyzed olivines in this unit is due to re-equilibration during cooling.

Chromian spinels from Hole 917A have rather similar compositions to those from the Scoresby Sund basalts (Larsen et al., 1989) and the Paleogene picritic lavas of west-central Skye, Scotland (Bell and Williamson, 1994), but they are much more depleted in chromium than those from the Kangerlussuaq picrites of East Greenland (Nielsen et al., 1981). Spinels from the Upper Series have slightly lower $\mathrm{TiO}_{2}$ contents than those from the Lower Series, but these differences are too subtle to relate firmly to a change in the tectonic regime (Arai, 1992).

\section{Plagioclase}

Plagioclase phenocrysts are scarce in Hole 917A lavas and occur only in the more evolved basalts and the dacitic rocks; even in these rocks, the modal percentages rarely exceed 5\%. Only two units contain abundant plagioclase phenocrysts: the olivine-plagioclase-clinopyroxene-phyric basalt of Unit $60(12.8 \%)$ and the tuff of Unit 35B (26\%; Table 1). In the other samples, plagioclase is present mainly as elongated laths in the ophitic or intergranular matrix, or as microlites in the intersertal textures. Nonetheless, plagioclase is a major component in all of the petrographic types except in some picrites (Table 1).
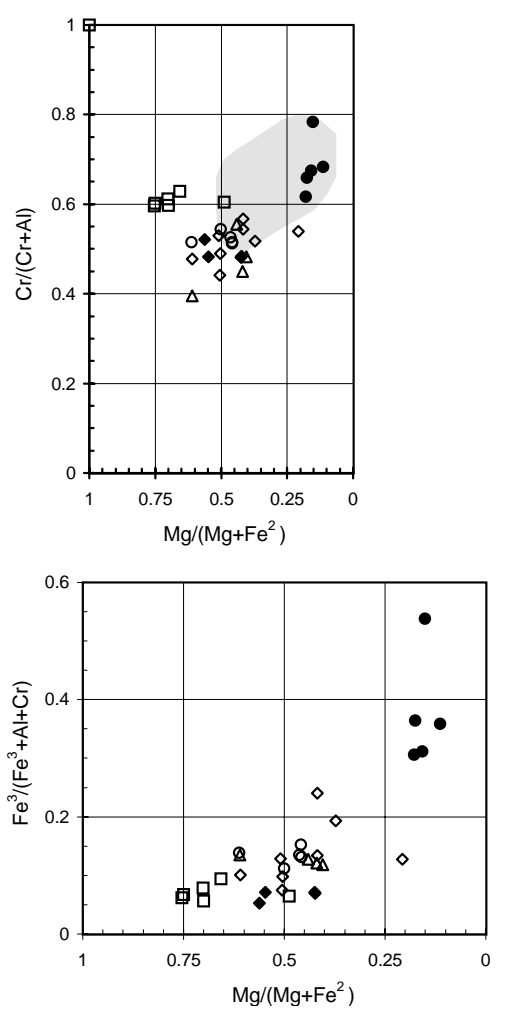
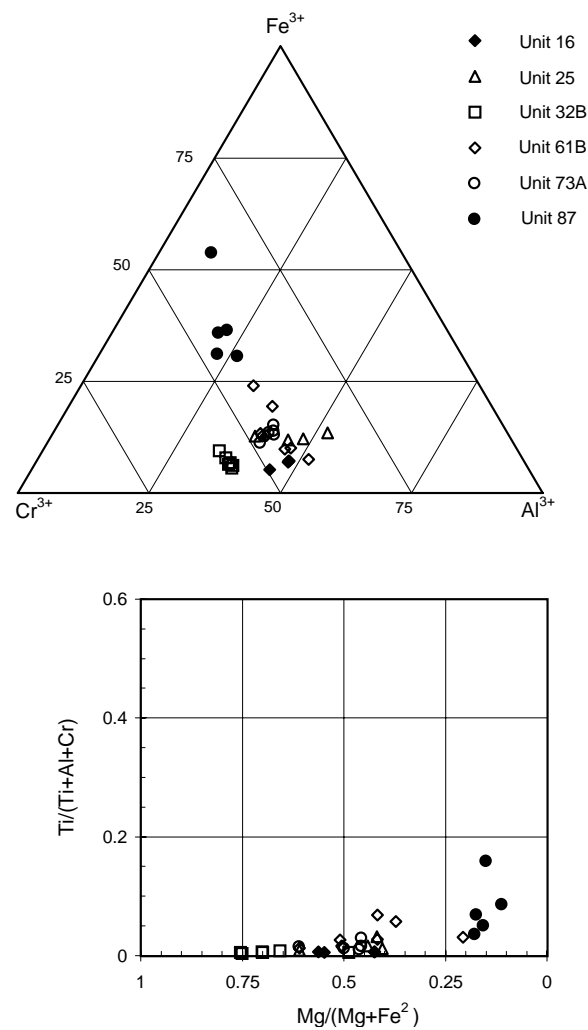

Figure 3. Composition of the spinels plotted on the different faces of the spinel prism (Irvine, 1965). See text for discussion. The gray zone on the $\mathrm{Cr} /(\mathrm{Cr}+\mathrm{Al}) \mathrm{vs} . \mathrm{Mg} /$ $\left(\mathrm{Mg}+\mathrm{Fe}^{2}\right)$ diagram corresponds to the composition of the spinels from the Scoresby Sund basalts (Larsen et al., 1989). 

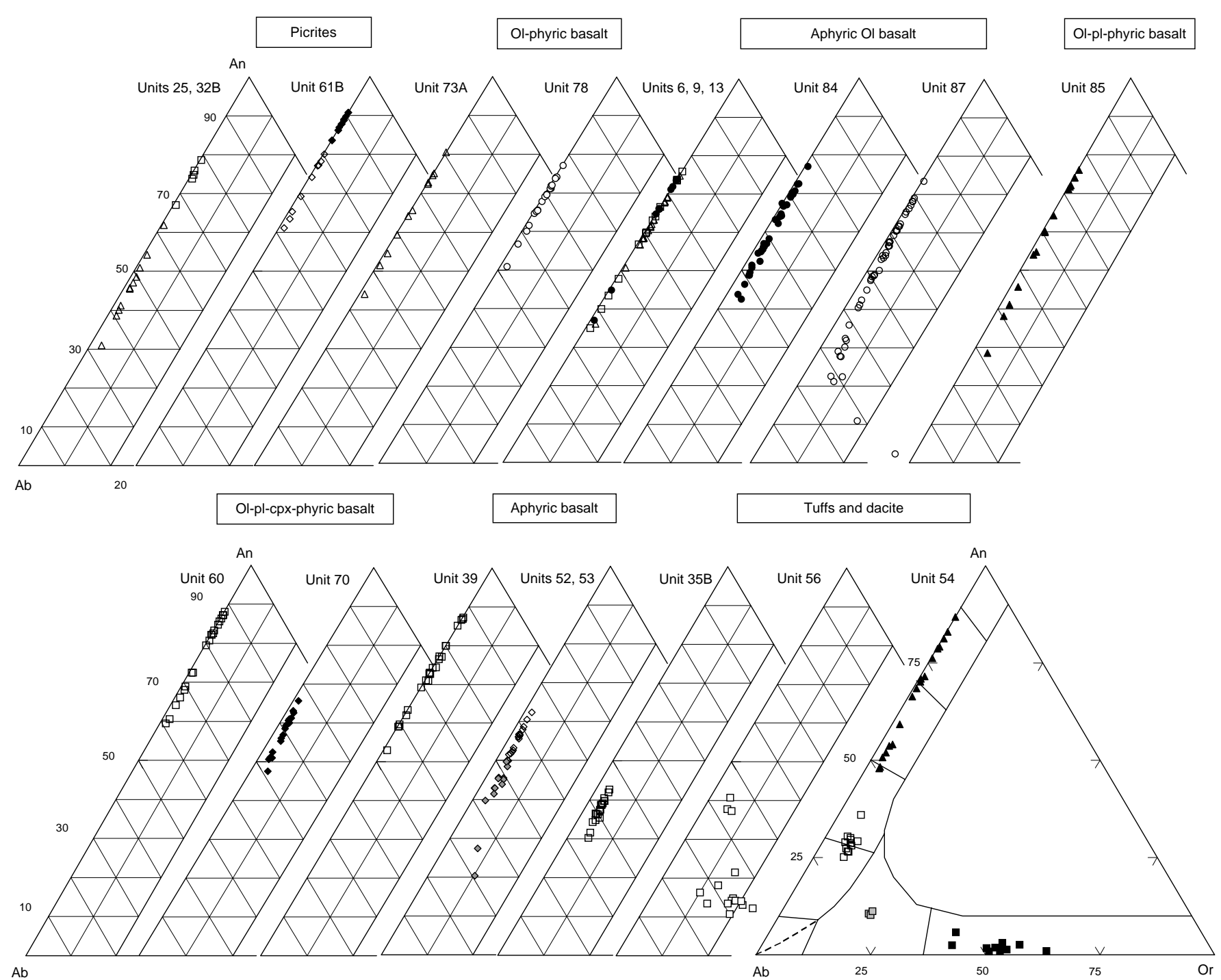

$\mathrm{Ab}$

Figure 4. Plagioclase compositions in the different petrographical types. Units 25, 32B: open squares = Unit 32B, open triangles $=$ Unit 25. Unit 61B: solid diamonds = plagioclase glomerocrysts, open diamonds = groundmass plagioclases. Units 6,9 , 13: open triangles = Unit 6 , solid circles $=$ Unit 9 , open squares = Unit 13. Units 52, 53: open diamonds = Unit 52, gray diamonds = Unit 53. Dacite of Unit 54: solid triangles = plagioclases from the basaltic fragments, open squares $=$ clear central part of the sieve-textured plagioclases, gray squares $=$ glass of the cloudy zone, solid squares $=$ glass of the groundmass recalculated as feldspar.

Plagioclase is sometimes altered to chlorite-smectite in the center of the larger crystals.

The highest anorthite $(\mathrm{An})$ content $\left(\mathrm{An}_{90.7}\right)$ was obtained on subhedral plagioclase that formed small crystal clots in Unit 61B picrite (Fig. 4). These crystals exhibit a broad central zone with complex but limited zoning $\left(\mathrm{An}_{90.7}-\mathrm{An}_{86.2}\right)$ and a more sodic rim that corresponds in composition to the plagioclase laths enclosed in the ophitic pyroxenes. For the plagioclase laths, there is a clear relationship between their size and composition, which evolved from $\mathrm{An}_{78.2}$ to $\mathrm{An}_{61}$.

The two analyzed picrites of the Upper Series (Units 25 and 32B) have contrasting plagioclase compositions (Fig. 4; Table 4). In Unit $32 \mathrm{~B}$, plagioclase is present as small bladed crystals partly enclosed by subequant clinopyroxenes; such a texture would indicate rapid eutectic crystallization of the groundmass. The compositional range of the plagioclase is limited $\left(\mathrm{An}_{78.6}-\mathrm{An}_{67.1}\right)$. In Unit 25, plagioclase is present as laths embedded in large ophitic pyroxene crystals. They are less calcic but show a wider compositional range $\left(\mathrm{An}_{61.9}-\mathrm{An}_{30.9}\right)$. The absence of more Ca-rich plagioclase in this rock is probably due to the fact that the cores of the larger crystals are heavily altered to chlorite and this rock is slightly more evolved as indicated by its $\mathrm{Mg}$ number (70.16).

Olivine-phyric basalts (Units 73A and 78), which have a subophitic texture, exhibit near-similar plagioclase compositional ranges, between $\mathrm{An}_{80}$ and $\mathrm{An}_{50}$. The higher An contents correspond to rare isolated euhedral phenocrysts; plagioclase laths enclosed by clinopyroxene have compositions in the range $\mathrm{An}_{65}-\mathrm{An}_{51}$; late crystallizing xenomorphic plagioclases are the more sodic.

Plagioclases from the aphyric olivine basalts show some interesting differences (Fig. 4). The diagram representing the plagioclase compositions of the Upper Series aphyric olivine basalts is a compilative plot of Units 6,9 , and 13 , which have very similar trends. The larger crystals are subequant with compositions ranging from $\mathrm{An}_{75.9}$ to $\mathrm{An}_{53}$, whereas all the analyses with less than $\mathrm{An}_{50}$ correspond to late crystallizing lath shaped plagioclase. Even the Na-rich plagioclases are very poor in potassium $\left(\mathrm{Or}_{0.9}\right.$ for $\left.\mathrm{An}_{35}\right)$. This is a clear contrast to the plagioclases from the Lower Series (Units 84 and 87), which have a significant orthoclase (Or) component for An $<60$ (Fig. 4). Units 84 and 87 are thick lava flows (45 and $35 \mathrm{~m}$, respectively) 
with perfect ophitic textures. Plagioclase laths have compositions ranging from $A n_{75}$ to $A n_{55}$, whereas the outer rims and the interstitial crystals are enriched in $\mathrm{Na}$ (down to $\mathrm{An}_{42}$ ). The more complete trend is observed in Unit 87. In this rock, the late crystallizing phases are represented by skeletal feldspars that have fractionated as far as $\mathrm{An}_{21}$; few anorthoclase have been also analyzed (Table 4; Fig. 4).

Except for Unit 70, olivine-plagioclase-phyric, olivine-plagioclase-clinopyroxene-phyric, and plagioclase-phyric basalts contain relatively high-calcium plagioclase phenocrysts. Even the phenocrysts, in Unit 70 , are relatively calcium-poor $\left(\mathrm{An}_{65.6}\right)$, whereas interstitial plagioclases are $\mathrm{An}_{48}$. In Unit 60, plagioclase phenocrysts are abundant $(12.8 \%)$ and slightly zoned $\left(\mathrm{An}_{88}-\mathrm{An}_{79.5}\right)$. A small outer rim can be clearly observed under the microscope, and this zone has the same composition as the microlites of the matrix $\left(\mathrm{An}_{72.5}-\mathrm{An}_{59.5}\right)$. Such a difference correlates with the degree of differentiation as indicated by the Mg numbers (61.97 for Unit 60, 54.76 for Unit 70). Unit 85 (olivine-plagioclase-phyric basalt) contains very few plagioclase phenocrysts (Table 1 ). The relatively large compositional range $\left(\mathrm{An}_{76}-\mathrm{An}_{28.5}\right)$ is in accordance with the ophitic texture of this rock.

The aphyric basalt from the dike (Unit 39) contains plagioclase laths with bytownite composition $\left(\mathrm{An}_{87}-\mathrm{An}_{85}\right)$; the smaller crystals and microlites range from $\mathrm{An}_{77}$ to $\mathrm{An}_{59}$. The 52-m-thick aphyric basalt, Unit 52, has a very fine-grained intergranular groundmass made of about $50 \%$ plagioclase (Table 1$)$. These plagioclases $(0.3-0.2 \mathrm{~mm})$ have a limited compositional range $\left(\mathrm{An}_{62.4}-\mathrm{An}_{50}\right)$. Such a labradorite composition corresponds well with the chemistry of this differentiated basalt $(\mathrm{Mg}$ number $=51.88)$. Unit 53, the quenched glassy base of Unit 52, contains skeletal plagioclase microlites whose compositions are slightly more sodic.

Plagioclase phenocrysts are abundant and exhibit euhedral morphologies $(1-3 \mathrm{~mm})$ in the glassy porphyritic tuff (Unit 35B). They are weakly zoned and range in composition from $\mathrm{An}_{43}$ to $\mathrm{An}_{30}$. These compositions plot on a trend similar to the one defined by the late crystallizing feldspars of Unit 87. Similar oligoclase to andesine compositions $\left(\mathrm{An}_{36}-\mathrm{An}_{26.5}\right)$ are observed in Unit 54 dacite. However, most of these phenocrysts are sieve-textured and contain abundant glass inclusions so that only small clear remnants are preserved in the center of the crystals. The analyses obtained on the cloudy zone show that it corresponds to a mixture of plagioclase and glass whose composition $\left(\mathrm{An}_{10} \mathrm{Or}_{20}\right)$ is intermediate between that of the oligoclase and that of the glass present in the groundmass (Fig. 4). This dacitic lava also contains bytownite to labradorite plagioclase phenocrysts $\left(\mathrm{An}_{86.4}-\mathrm{An}_{66.4}\right)$ that are present as isolated crystals or in aggregates with clinopyroxene. The microlites analyzed in the glass outside these glomerocrysts are also more calcic than the cloudy plagioclase phenocrysts. This bimodal plagioclase population clearly indicates that Unit 54 dacite, as supported by on-board, hand-specimen observation, is in fact a mixed lava composed of basaltic fragments incorporated into an acidic liquid at the moment of eruption. The plagioclase and clinopyroxene phenocrysts present in the fragments have compositions very similar to those of olivine-plagioclase-phyric or olivine-plagioclase-clinopyroxene-phyric basalts (Fig. 5). The dacitic glass of the spherulitic structures, recalculated as feldspar, plots in the field of sanidine (Fig. 4).

The eutaxitic tuff (Unit 56) also contains cloudy plagioclases slightly more calcic in the core than those of the dacite (andesine, $\mathrm{An}_{41}-\mathrm{An}_{37}$ ). Glassy inclusions are abundant in the outer rims; the mean composition of the glass $\left(\mathrm{An}_{13.7} \mathrm{Or}_{19.5}\right)$ is very similar to that of Unit 54 (Fig. 4).

Plagioclases are not renowned for being very useful at characterizing magmatic sequences. However, it is apparent from the aphyric olivine basalts that differences are observed between the Upper Series lavas, whose compositional trends show a limited enrichment in Or, and the Lower and Middle Series lavas, which exhibit a regular increase in potassium and an evolution toward anorthoclase compositions during the crystallization path. This difference is real, although the bulk rock analyses of the Upper and Lower Series do not show clear differences in $\mathrm{K}_{2} \mathrm{O}$ (Fitton et al., Chap. 28, this volume). As Units 6, 9, and 13 come from the heavily altered upper part of the volcanic pile where zeolites are abundant (Demant et al., this volume), it is probable that originally existing differences in $\mathrm{K}_{2} \mathrm{O}$ content have been blurred by post-cooling circulating hydrothermal fluids.

\section{Pyroxenes}

Clinopyroxene is absent as a phenocryst phase in Hole 917A basalts, except in the rare olivine-plagioclase-clinopyroxene-phyric basalts. Nevertheless, it is one of the principal components in the matrix (Table 1). Groundmass clinopyroxene varies in size from small microlites, in the intersertal rocks, to large oikocryst (up to $5 \mathrm{~mm}$ ) in the ophitic lavas. These crystals are colorless to light green in thin section. Pigeonite and orthopyroxene are not common and were clearly identified only by microprobe. Selected analyses of pyroxene are reported in Table 5.

The pyroxene analyses are plotted in the enstatite-diopsidehedenbergite-ferrosilite quadrilateral, following the classification of Morimoto et al. (1988). The chemistry of the pyroxenes broadly reflects that of the rock types and mostly reflects the cooling conditions as this mineral is a groundmass phase. Three different crystallization trends can be recognized (Fig. 5).

The first one is well defined by the picrites from the Upper Series (Units 25 and 32B). The analyses indicate an evolution trend characterized by a regular decrease of the wollastonite (Wo) and enstatite (En) end members during the crystallization; the compositions evolve from a Mg-rich augite pole, located near the limit with the diopsidic field $\left(\mathrm{Wo}_{44.7} \mathrm{En}_{43.9} \mathrm{Fs}_{11.4}[\mathrm{Fs}=\right.$ ferrosilite $\left.]\right)$, to a less calcic and more $\mathrm{Fe}$-rich type $\left(\mathrm{Wo}_{39.1} \mathrm{En}_{39.5} \mathrm{Fs}_{21.4}\right)$. Unit $61 \mathrm{~B}$ picrite from the Lower Series presents broadly the same trend. Pyroxenes of olivinephyric basalt Unit 78, which has a high Mg number (72.34), can be included in this same group as well as the aphyric olivine basalt of Unit 13. In this last sample, which is slightly more evolved (Mg number $=65.46$ ), the trend shows a tendency toward low-calcium augites. This kind of evolution, characterized by limited Fe-Mg substitutions, is observed in relatively thin lava flows and corresponds to the rapid crystallization of subophitic clinopyroxene in the groundmass.

The second group is represented by Units 84 and 87 aphyric olivine basalts (Lower Series). Pyroxene compositions evolve from calcium- and magnesium-rich augites $\left(\mathrm{Wo}_{43.6} \mathrm{En}_{46.4} \mathrm{Fs}_{10}\right)$ to iron-rich and calcium-poor augites $\left(\mathrm{Wo}_{35.8} \mathrm{En}_{44.8} \mathrm{Fs}_{19.4}\right)$. Compared to the picritic augites, these clinopyroxenes have an overall higher $\mathrm{MgO}$ content but are slightly less calcic. At a $\mathrm{Mg} /(\mathrm{Mg}+\mathrm{Fe})$ ratio of about 70 , the Ca-content drops rapidly toward pigeonite (Unit 84) or orthopyroxene compositions (Unit 87). As indicated by their $\mathrm{Mg} /(\mathrm{Mg}+\mathrm{Fe})$ ratios and their size and location, pigeonite and orthopyroxene are the last minerals to crystallize. The aphyric basalt of Unit 52 presents the same kind of compositional evolutionary trend, but, as with the rock, augites and pigeonites are slightly more evolved (lower $\mathrm{Mg} /(\mathrm{Mg}+\mathrm{Fe}$ ) ratios). This trend is characteristic of samples collected in the central part of thick lava flows ( $>30 \mathrm{~m}$ ) where slow cooling rates induce perfect ophitic textures.

The third group corresponds to the most differentiated lavas, which are the olivine-plagioclase-phyric, olivine-plagioclase-clinopyroxene-phyric, plagioclase-phyric basalts and dacites. In this group, the textures are mainly intersertal to intergranular, and pyroxene crystallizes either as subequant microphenocrysts or very thin microlites that are difficult to analyze in the groundmass. Even if the evolution is relatively limited in terms of the $\mathrm{Mg} /(\mathrm{Mg}+\mathrm{Fe})$ ratio, the representative points on the diagrams are more scattered than in the other two groups (Fig. 5). This seems to be due to the presence of sector zoning, visible in thin section, which induces notable differences in chemistry between the two sectors (Hollister and Gancarz, 1971; Wass, 1973; Leung, 1974). In Unit 60, some analyses plot in the diopside field $\left(\mathrm{Wo}_{46.3} \mathrm{En}_{44.7} \mathrm{Fs}_{9}\right)$ and they correspond to pyroxene mi- 

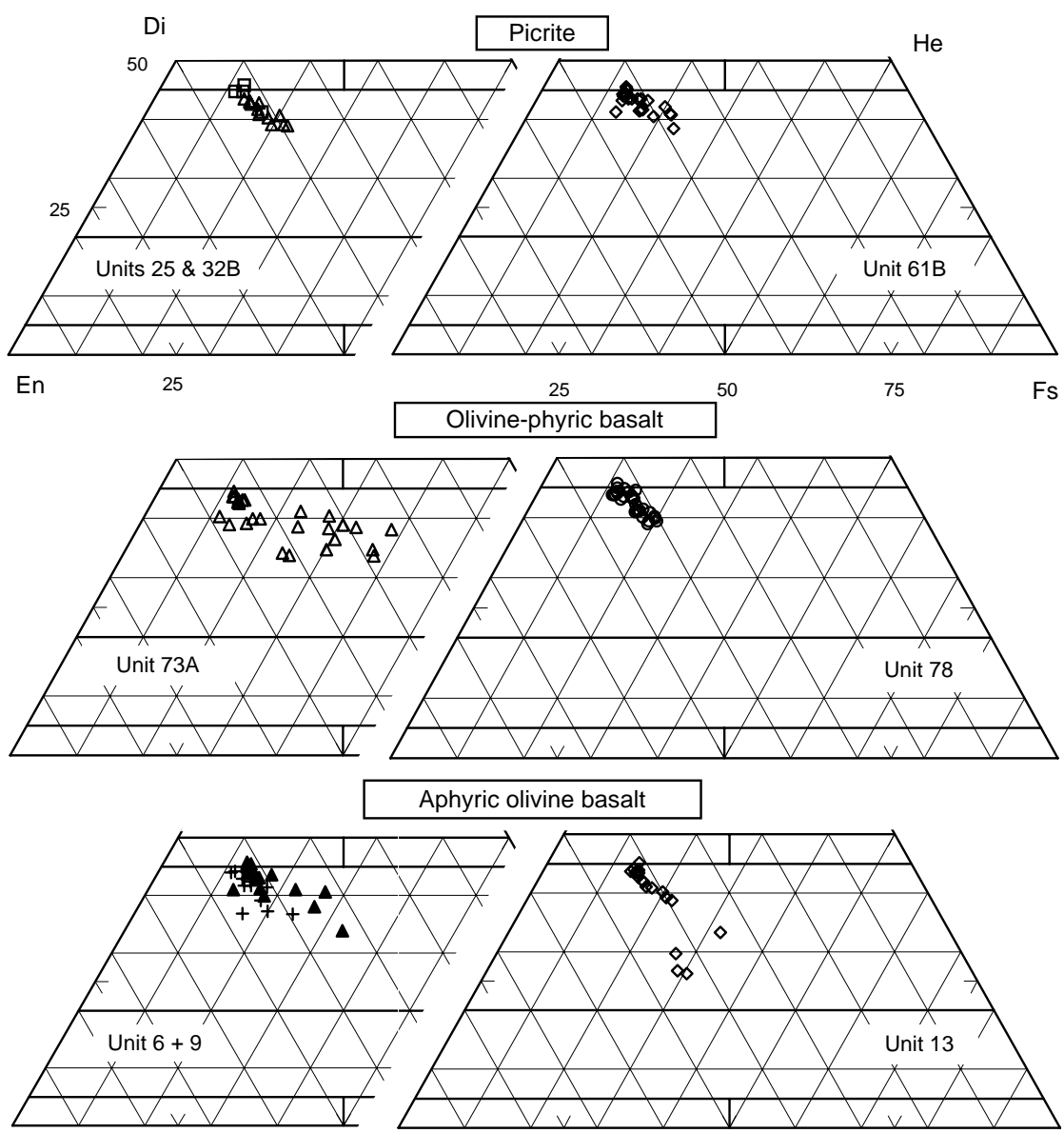

Figure 5. Pyroxene compositions in representative rocks from Hole 917A. Picrites: Unit $25=$ open triangles, Unit $32=$ open squares. Aphyric olivine basalts: Unit $6=$ solid triangles, Unit $9=$ crosses. Dacites: open triangles $=$ Unit 54, open squares $=$ Unit 56 .

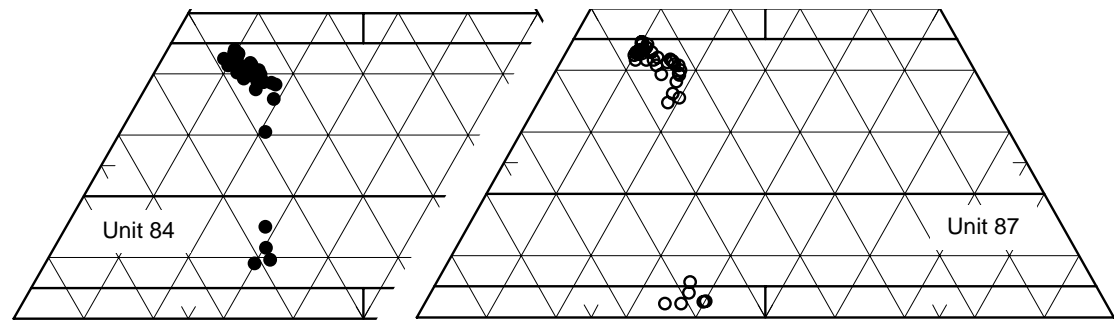

crophenocrysts associated with bytownite in crystal clots. The trends observed for Units 85 and 70 are very similar to that of Unit 60. In Unit 70, some pyroxene microphenocrysts present two different zones distinguished by changes of extinction position and the abundance of minute inclusions. In the dacite (Unit 54), most of the clinopyroxenes are similar to those found in the evolved basalts and correspond therefore to the mafic component of this mixed lava. One analysis gives a $\mathrm{Fe}$-rich composition $\left(\mathrm{WO}_{38.8} \mathrm{En}_{35.1} \mathrm{Fs}_{26.1}\right)$ similar to that of pyroxenes from the acidic tuffs (Units 35B and 56; Fig. 5). It is the only crystal in equilibrium with the acidic component. Pyroxenes from the dike (Unit 39) exhibit peculiar plumose endings. Such a morphology, associated with a tendency for the plagioclase to form spherulitic aggregates, is characteristic of doleritic dikes and coarse-grained variolitic basalts (MacKenzie et al., 1982; Schrader and Stow, 1983).

The pyroxene trends in the subophitic olivine-phyric basalt of Unit 73A and aphyric olivine basalts of Units 6 and 9 are peculiar as they show both a prolonged trend characteristic of normal zonation and a relative dispersion due to sector zoning.

The pyroxene crystallization trends in the tholeiitic series are generally complex because they depend upon numerous factors such as the chemistry of the lavas, the cooling conditions, the crystallization of plagioclase, and further re-equilibration with the liquid (Hall et al., 1986). The cooling rate seems to be the main factor that influences the compositional trends of the pyroxenes in Hole 917A. Sector zoning, however, has a scattering effect on the trends as observed for the evolved basalts.

When plotted together, the pyroxene compositions define a typical tholeiitic trend similar to that of the Scoresby Sund basalts (Larsen et al., 1989), which in turn broadly follows the reference trend of the Skaergaard intrusion (Brown and Vincent, 1963). This tholeiitic character is also underlined by the low $\mathrm{Ti}$ values $(\mathrm{Ti}<0.05) . \mathrm{TiO}_{2}$ is slightly higher in the picritic rocks $(>1 \%) . \mathrm{Cr}_{2} \mathrm{O}_{3}$ is up to $1.3 \%$ in the more magnesian augites $\left(\mathrm{Fs}_{9}-\mathrm{Fs}_{10}\right)$ but drops rapidly toward zero at $\mathrm{Fs}_{13}-\mathrm{Fs}_{15}$. This regular decrease of the chromium content with crystallization is well observed in the large oikocryst in the ophitic rocks. The low alumina contents and low $\mathrm{Al}^{\mathrm{VI}} / \mathrm{Al}^{\mathrm{IV}}$ ratios of the clinopyroxenes, even in the microphenocrysts present in the olivine-plagioclase-clinopyroxene-phyric basalts (Units 60 and 70), are in accordance with low-pressure crystallizing conditions (Aoki and Kushiro, 1968; Gasparik, 1984).

On binary diagrams where elements are plotted against the $\mathrm{Fe} /$ $(\mathrm{Fe}+\mathrm{Mg})$ ratio, negative correlations are observed for $\mathrm{Cr}, \mathrm{Al}$, and at a lesser scale for $\mathrm{Ca}$, whereas $\mathrm{Si}, \mathrm{Ti}$, and $\mathrm{Na}$ show positive correlations. 

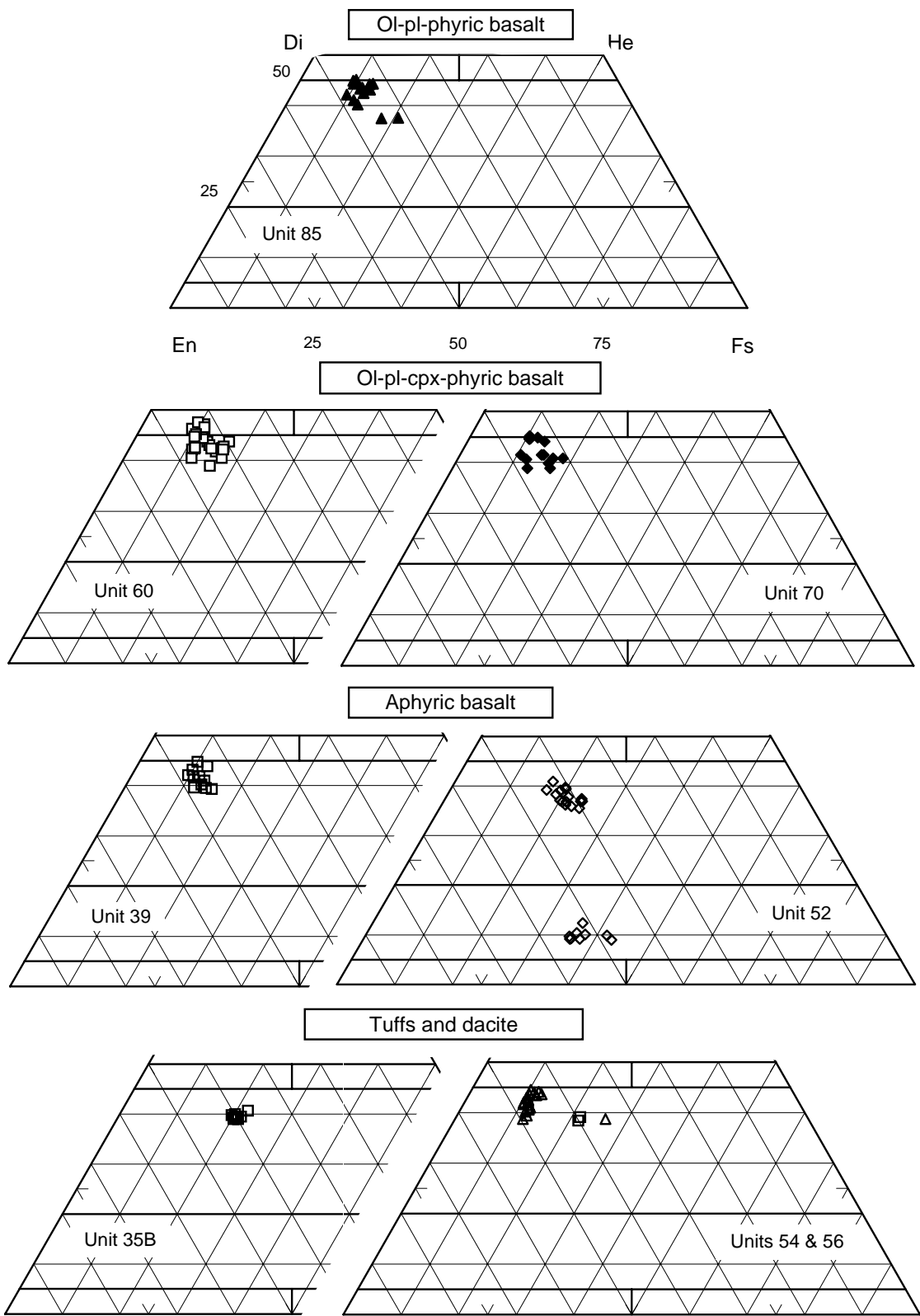

Figure 5 (continued).

The correlation lines are very regular, except for clinopyroxene microphenocrysts from the porphyritic lavas, which exhibit more scattered trends, especially for $\mathrm{Al}$ and $\mathrm{Si}$ because of direct influence of sector zoning.

The coexistence of different kinds of pyroxenes in Units 84, 87, and 52 enables the use of the pyroxene thermometers. The augitepigeonite association gives equilibrium temperatures in the range $1050^{\circ}-1000^{\circ} \mathrm{C}$ for the aphyric olivine basalt (Unit 84 ), and $1000^{\circ}-$ $950^{\circ} \mathrm{C}$ for the more evolved aphyric basalt (Unit 52), using the method of Wood and Banno (1973). Temperatures for the orthopyroxeneaugite association present in Unit 87 are slightly lower (around $940^{\circ} \mathrm{C}$ ). Temperatures obtained with the Lindsley (1983) geothermometer are in the same range, between $1050^{\circ} \mathrm{C}$ and $900^{\circ} \mathrm{C}$.

In conclusion, pyroxene chemistry of Hole 917A lavas shows that:

1. There are no clear differences in the pyroxene compositions between the Upper and the Lower or Middle Series;

2. The different trends observed on the enstatite-diopside-hedenbergite-ferrosilite diagrams reflect mostly differences in the cooling conditions rather than differences in the chemistry of the whole rocks; and

3. The pyroxenes are low-pressure phases typical of tholeiitic liquids in which clinopyroxene forms mainly in the groundmass. Pigeonite starts to crystallize at about $1050^{\circ} \mathrm{C}$, whereas orthopyroxene appears at lower temperatures.

\section{Fe-Ti oxides}

Titanomagnetites and ilmenites are groundmass phases in all of the lavas except for the dacitic rocks. These minerals are therefore mostly subhedral to anhedral. In the rapidly chilled rocks containing glass, the Fe-Ti oxides have skeletal development that is cruciform for titanomagnetite and bladed for ilmenite. Due to the small size of the crystals, their interstitial position and the presence of oxidized rims around some olivine phenocrysts, modal percentages of opaque oxides are only roughly estimated, but tend to increase in the more differentiated lavas (Table 1). Titanomagnetite predominates in most of the samples, but ilmenite is not ubiquitous. Titanomagnetite is frequently slightly oxidized, which is consistent with the low totals of 
the microprobe analyses (Table 6). This is more common in the ophitic textures and therefore clearly related to slow cooling rates. The greatest compositional ranges are observed in Units 84 and 87 with ophitic textures $\left(\mathrm{Usp}_{28}-\mathrm{Usp}_{45}\right.$ in Unit 87 [Usp $=$ ulvöspinel]). The high titanium content of the magnetites $(10 \%-26 \%$ with a mean of $20 \%$ ) characterizes titaniferous magnetite (Buddington and Lindsley, 1964; Deer et al., 1980). $\mathrm{TiO}_{2}$ contents of the magnetites are highest in the picritic rocks $\left(\mathrm{Usp}_{67}-\mathrm{Usp}_{71}\right)$, whereas the ulvöspinel component has a tendency toward lower values $\left(\mathrm{Usp}_{47}-\mathrm{Usp}_{49}\right)$ in the dacite and the tuff (Usp ${ }_{35}-\mathrm{Usp}_{38}$; Fig. 6). Ilmenite compositions evolved slightly during the differentiation from $\mathrm{Hem}_{5}$ in the picrite to $\mathrm{Hem}_{20}$ in the tuff (Unit 35B; Hem = hematite).

Temperatures and oxygen fugacities can be estimated using homogeneous titanomagnetite and ilmenite coexisting pairs. $\mathrm{Mg} / \mathrm{Mn}$ partitioning between magnetite and ilmenite (Bacon and Hirschmann, 1988) was used as a test for equilibrium between coexisting Fe-Ti oxides. The temperatures obtained using the titanomagnetiteilmenite geothermometer (Carmichael, 1967; Anderson, 1968; Andersen and Lindsley, 1985) are in the range $1050^{\circ}-820^{\circ} \mathrm{C}$. The highest temperatures correspond to the picrites (Units 61B and 25). Temperatures obtained for the ophitic samples from Units 84 and 87 are consistent with those deduced from the two-pyroxenes geothermometer, but about $100^{\circ} \mathrm{C}$ lower. These temperatures are therefore most probably exsolution temperatures and not liquidus temperatures. Observations made on the Kilauea Iki lava lake in Hawaii (Helz and Thornber, 1987) show that magnetite-ilmenite pairs coexist below $1090^{\circ} \mathrm{C}$, whereas during melting experiments on Icelandic basalts (Thy and Lofgren, 1994), Fe-Ti oxide minerals begin to crystallize at $1105^{\circ} \mathrm{C}$ independently of the composition of the liquid. On a diagram $\mathrm{T}^{\circ} \mathrm{C}$ vs. $\log \mathrm{fO}_{2}$ (Spencer and Lindsley, 1981), the points representing the picritic basalts (Units 25 and 61B) and olivine-plagioclase-clinopyroxene-phyric basalt (Unit 70) lie on the synthetic fayalite-magnetite-quartz (FMQ) buffer curve while the aphyric olivine basalts (Units 84 and 87) plot on the nickel-nickel oxide (NNO) curve (Fig. 7). The low oxygen fugacities for the picrites are consistent with the conclusion deduced from the composition of the spinels, while the high oxygen fugacities in Units 84 and 87 are in accordance with slow cooling rates due to the position of these samples in the central part of thick lava flows. Temperatures obtained for Unit 35B (Tuff), around $1000^{\circ} \mathrm{C}$, seem to be the only liquidus temperature.

\section{Glass}

The lavas from Hole 917A contain varying proportions of glass, depending on the cooling conditions. Fresh glass is, however, very rare, being generally altered to green clays. Glass is abundant in the acidic rocks (dacites and tuffs) and in Unit 53, the glassy base of Unit 52. In Unit 53, the original quenched glassy matrix presents different stages of alteration ranging from palagonitization to a complete transformation to smectites (Demant et al., this volume). The palagonitized glass contains about $10 \% \mathrm{H}_{2} \mathrm{O}$. A net loss of $\mathrm{Fe}, \mathrm{Mg}, \mathrm{Ca}$, and a correlative increase of silica and alkalies is apparent from the chemical analysis (Table 7). Glasses from the aphyric olivine basalt (Unit 13) and the olivine-phyric basalt (Unit 78) are also slightly hydrated $\left(7 \%-8 \% \mathrm{H}_{2} \mathrm{O}\right)$, but in this case $\mathrm{Fe}$ and $\mathrm{Mg}$ do not decrease compared to their values in the whole rock analyses. The chemical fluxes concern principally $\mathrm{Ca}$, which is heavily leached, and the alkalies, which increase greatly (from $2.1 \%$ to $4.5 \%$ for the sodium and from $0.1 \%$ to $0.5 \%$ for the potassium). In the dacite (Unit 54), the devitrified glass from the spherulites has a composition very similar to that of K-feldspar (Table 7, and therefore plots in the field of sanidine on the anorthite-albite-orthoclase diagram (Fig. 4), whereas the glassy matrix outside the spherulites is heavily altered to clay minerals (Demant et al., this volume). The glass analyzed on a black fiamme present in the welded tuff (Unit 56) has a dacitic composition similar to that of the whole-rock (Fitton et al., Chap. 28, this volume), but $\mathrm{MgO}$ and $\mathrm{CaO}$ are slightly lower, and $\mathrm{K}_{2} \mathrm{O}$ higher.

\section{CONCLUSIONS}

Rocks drilled at Hole 917A are relatively fresh and enable a detailed study of their primary mineralogy. The good recovery has ensured a representative sampling of the Paleogene volcanic succession
Figure 6. Titanomagnetite and ilmenite compositions in the $\mathrm{TiO}_{2}-\mathrm{FeO}-\mathrm{Fe}_{2} \mathrm{O}_{3}$ diagram. Picrites: triangles $=$ Unit 25, diamonds $=$ Unit 61B. Ol-phyric basalt: open squares $=$ Unit 73A; open triangles $=$ Unit 78 . Aphyric olivine basalts: open triangles $=$ Unit 9; open diamonds $=$ Unit 13; solid circles $=$ Unit 84; open circles $=$ Unit 87. Ol-pl-cpx-phyric basalts: open squares $=$ Unit 60 ; solid diamonds $=$ Unit 70. Dacites: open squares $=$ Unit 35B, open triangles $=$ Unit 54 .
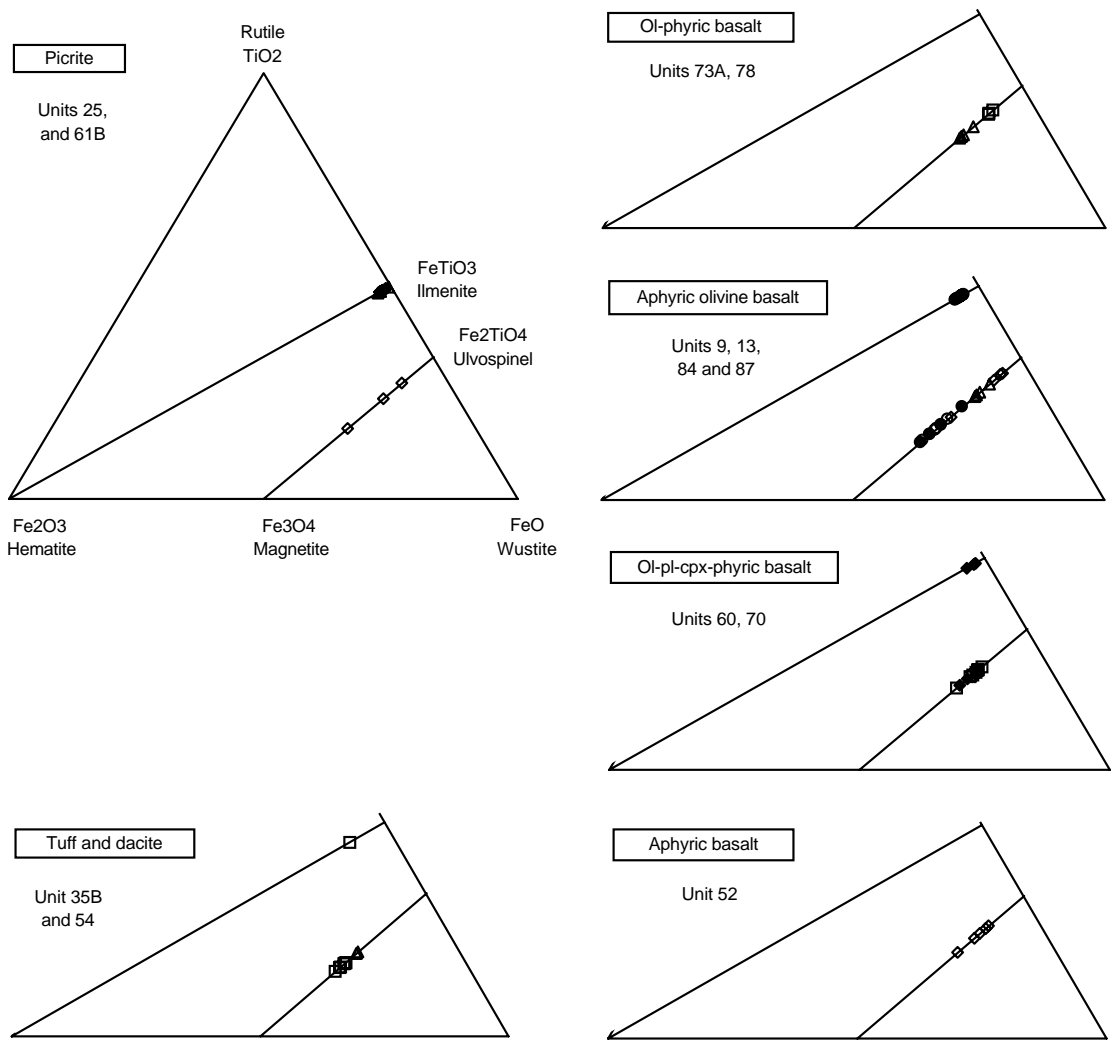


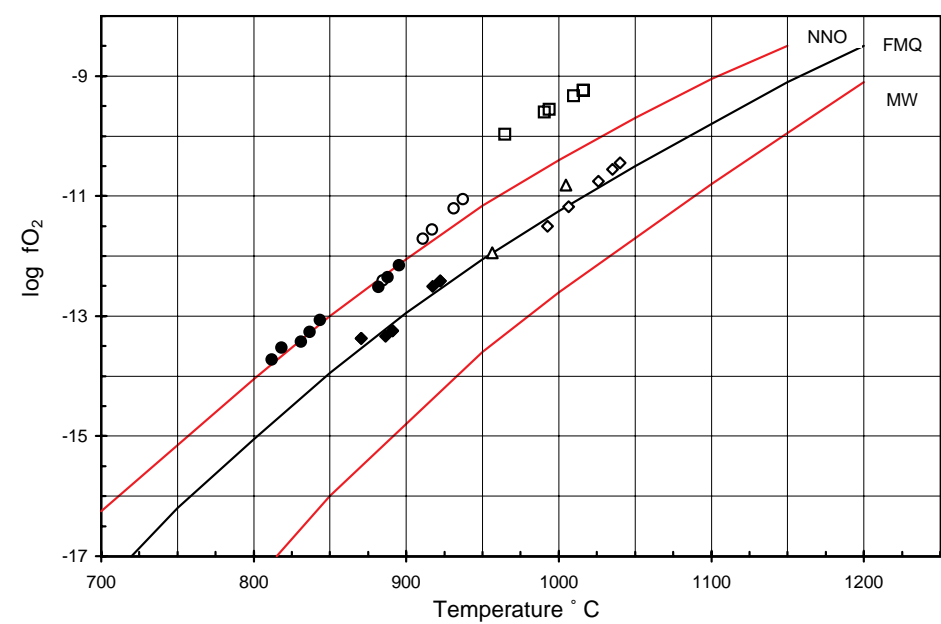

$\Delta$ Unit 25

口 Unit 35B

$\diamond$ Unit 61B

- Unit 70

○ Unit 84

- Unit 87
Figure 7. Temperatures and oxygen fugacities for coexisting titanomagnetite-ilmenite pairs (after Spencer and Lindsley, 1981). that erupted during the early stage of opening of the North Atlantic, in a continental rift environment.

Picritic lavas are frequent in the Upper Series. Some lava flows (Unit 32B) contain fresh olivine phenocrysts with very high forsterite contents $\left(\mathrm{Fo}_{92.4}\right)$, enclosing early-formed $\mathrm{Cr}$-spinels. These olivines, in equilibrium with the liquid, characterize high- $\mathrm{Mg}$ magmas that originated from a hot mantle source and were rapidly emplaced to the surface during the final continental breakup. Basalts with $\mathrm{MgO}$ contents above $20 \%$, such as Units 21 and 32 are, however, probably somewhat cumulitic. Plagioclases present in the aphyric olivine basalts associated with the picrites have very low K contents compared to those of the Lower Series. As this difference is not actually reflected by the chemistry of the whole rocks, it is apparent that the postcooling hydrothermal circulations that have heavily altered the upper part of the volcanic pile have also helped to smear out any original differences. A study of the secondary minerals (Demant et al., this volume), particularly the zeolites, clearly shows that this hydrothermal system has affected the entire volcanic pile.

Primitive liquids are less frequent in the Middle and Lower Series, which corresponds well with the tectonic regime prevailing during the pre-breakup continental rifting. Alternate primitive and more differentiated magmas of these series support the existence of a periodically refilled magma reservoir. Crustal contamination evidenced by the geochemistry (Fitton et al., 1995; Fitton et al., Chap. 28, this volume) is not illustrated by the presence of crustal xenoliths in the lavas. The forsterite content of the olivine is an indicator of fractionation for the basalts. However, in the case of rocks with ophitic textures (slow cooling rates), re-equilibration with the liquid occurred during groundmass crystallization, and olivine has lower Fo contents than the calculated Fo values. Clinopyroxene was never found as phenocrysts, but it is predominant in the groundmass. Pigeonite and orthopyroxene are present in some aphyric olivine basalts and aphyric basalts. An application of the pyroxene thermometers gives temperatures in the range $1050^{\circ}-950^{\circ} \mathrm{C}$ for these late-crystallizing phases. The compositional trend, characterized by a progressive decrease in the $\mathrm{Ca}$ and $\mathrm{Mg}$ contents and low Ti contents, is typical of tholeiitic series. The differences observed on the pyroxene trends reflect differences in the cooling conditions.

Plagioclases are not very useful to discriminate magmatic series. The trends obtained for the different petrographical types show a progressive decrease of the Ca content of the plagioclase with the differentiation.

The chemistry of the mineral phases present in the dacitic lava (Unit 54) helped to identify the two magmatic components of this mixed lava. The basaltic component is a relatively evolved basalt containing bytownite and augite phenocrysts. The acidic component, mainly glassy, contains scarce Fe-rich, augite microphenocrysts, sieve-textured plagioclases $\left(\mathrm{An}_{30}\right)$, and quartz. Similar dacitic rocks were found on the Vøring Plateau (Vierek et al., 1989), and interpreted as the mixing product of mantle-derived tholeiites with melts produced by partial fusion of the continental crust. At Hole 917A, the acidic melt has geochemical signatures clearly influenced by assimilation of Archean gneiss (Fitton et al., Chap. 28, this volume).

These data on the primary and secondary (Demant et al., this volume) mineralogy, along with the geochemical studies, help to decipher the petrogenetic processes that occurred during the rifting and progressive thinning of the continental crust that just preceded the opening of the North Atlantic.

\section{ACKNOWLEDGMENTS}

This paper has benefited from detailed reviews and comments by L.M. Larsen, H. Lapierre, A.D. Saunders, and the ODP editor. J.G. Fitton and A.D. Saunders provided the geochemical data set used for correlation between the mineralogy and the chemistry of the lavas. C. Merlet is thanked for help with the microprobe at Montpellier University. The shore-based research has been funded by a CNRS-INSU grant (Géosciences marines 94GEO1/3.01).

\section{REFERENCES}

Albarède, F., and Tamagnan, V., 1988. Modelling of recent geochemical evolution of the Piton de la Fournaise volcano, Réunion Island. J. Petrol., 29:997-1030.

Allan, J.F., 1992. Cr-spinel as a petrogenetic indicator: deducing magma composition from spinels in highly altered basalts from the Japan Sea, Sites 794 and 797. In Tamaki, K., Suyehiro, K., Allan, J., McWilliams, M., et al., Proc. ODP, Sci. Results, 127/128 (Pt. 2): College Station, TX (Ocean Drilling Program), 837-847.

Andersen, D.J., and Lindsley, D.H., 1985. New (and final) models for the Timagnetite/ilmenite geothermometer and oxygen barometer. Eos, 66:416.

Anderson, A.T., 1968. The oxygen fugacity of alkaline basalts and related magmas, Tristan Da Cunha. Am. J. Sci., 266:704-727.

Aoki, K.I, and Kushiro, I., 1968. Some clinopyroxenes from ultramafic inclusions in Dreiser Weiher, Eifel. Contrib. Mineral. Petrol., 18:326337.

Arai, S., 1992. Chemistry of chromian spinels in volcanic rocks as a potential guide to magma chemistry. Mineral. Mag., 56:173-184.

Bacon, C.R., and Hirschmann, M.M., 1988. Mg/Mn partitioning as a test for equilibrium between coexisting Fe-Ti oxides. Am. Mineral., 73:57-61.

Bell, B.R., and Williamson, I.T., 1994. Picritic basalts from the Palaeocene lava field of west-central Skye, Scotland: evidence for parental magma compositions. Mineral. Mag., 58:347-356.

Boudier, F., 1991. Olivine xenocrysts in picritic magmas: an experimental and microstructural study. Contrib. Mineral. Petrol., 109:114-123.

Brown, G.M., and Vincent, E.A., 1963. Pyroxenes from the late stages of fractionation of the Skaergaard intrusion, East Greenland. J. Petrol., 4:175-197. 
Buddington, A.F., and Lindsley, D.H., 1964. Iron-titanium oxides minerals and synthetic equivalents. J. Petrol., 5:310-357.

Carmichael, I.S.E., 1967. The iron-titanium oxides of salic volcanic rocks and their associated ferromagnesian silicates. Contrib. Mineral. Petrol., 14:36-64.

Deer, W.A., Howie, R.A., and Zussman, J., 1980. An Introduction to the Rock-Forming Minerals: London (Longman).

Demant, A., Cambray, H., Vandamme, D., and Leg 152 Shipboard Scientific Party, 1995. Lithostratigraphy of the volcanic sequences at Hole 917A, Leg 152, Southeast Greenland margin. J. Geol. Soc. London, 152:943946.

Eldholm, O., Thiede, J., Taylor, E., et al., 1989. Proc. ODP, Sci. Results, 104: College Station, TX (Ocean Drilling Program).

Fitton, J.G., Saunders, A.D., Larsen, L.M., Fram, M.S., Demant, A., Sinton, C.W., and Leg 152 Shipboard Scientific Party, 1995. Magma sources and plumbing systems during break-up of the SE Greenland margin: results from ODP Leg 152. J. Geol. Soc. London, 152:985-990.

Ford, C.E., Russell, D.G., Craven, J.A., and Fisk, M.R. 1983. Olivine-liquid equilibria: temperature, pressure and compositional dependence of the crystal/liquid cation partition coefficients for $\mathrm{Mg}, \mathrm{Fe}^{2+}, \mathrm{Ca}$, and $\mathrm{Mn} . J$. Petrol., 24:256-265.

Gasparik, T., 1984. Two pyroxene barometry with new experimental data in the system $\mathrm{CaO}-\mathrm{MgO}-\mathrm{Al}_{2} \mathrm{O}_{3}-\mathrm{SiO}_{2}$ Contrib. Mineral. Petrol., 87:87-94.

Hall, R.P., Hughes, D.J., and Friend, C.R., 1986. Complex sequential growth in tholeiitic hypabyssal rocks from southern West Greenland. Mineral. Mag., 50:491-502.

Helz, R.T., and Thornber, C.R., 1987. Geothermometry of Kilauea Iki lava lake, Hawaii. Bull. Volcanol., 49:651-668.

Hollister, L.S., and Gancarz, A.J., 1971. Compositional sector-zoning in clinopyroxene from the Narce area. Am. Mineral., 56:959-979.

Irvine, T.N., 1965. Chromium spinel as a petrogenetic indicator, Part 1: theory. Can. J. Earth Sci., 2:648-672.

Larsen, H.C., Saunders, A.D., Clift, P.D., et al., 1994. Proc. ODP, Init. Repts., 152: College Station, TX (Ocean Drilling Program).

Larsen, L.M., Watt, W.S., and Watt, M., 1989. Geology and petrology of the Lower Tertiary plateau basalts of the Scoresby Sund region, East Greenland. Bull.-Groenl. Geol. Unders., 157:1-164.

Leung, I.S., 1974. Sector-zoned titanaugites: morphology, crystal chemistry and growth. Am. Mineral., 59:127-138.

Lindsley, D.H., 1983. Pyroxene thermometry. Am. Mineral., 68:477-493.

MacKenzie, W.S., Donaldson, C.H., and Guilford, C., 1982. Atlas of Igneous Rocks and Their Textures: New York (Wiley).

Merlet, C., 1994. An accurate computer correction program for quantitative electron probe micro-analysis. Mikrochim. Acta, 114/115:363-376.
Morimoto, N., Fabries, J., Ferguson, A., Ginzburg, I., Roos, M., Seifert, F., and Zussman, J., 1988. Nomenclature of pyroxenes. Bull. Mineral., 111:535-550.

Nielsen, T.F.D., Soper, N.J., Brooks, C.K., Faller, A.M., Higgins, A.C., and Matthews, D.W., 1981. The pre-basaltic sediments and the lower basalts at Kangerlussuaq, East Greenland: their stratigraphy, lithology, paleomagnetism and petrology. Medd. Groenl., Geosci., 6:1-25.

Parson, L.M., Vierek, L.G., Love, D., Gibson, I.L., Morton, A.C., and Hertogen, J., 1989. The petrology of the lower series volcanics, ODP Site 642. In Eldholm, O., Thiede, J., Taylor, E. et al., Proc. ODP, Sci. Results, 104: College Station, TX (Ocean Drilling Program), 419-428.

Roberts, D.G., Backman, J., Morton, A.C., Murray, J.W., and Keene, J.B., 1985. Evolution of volcanic rifted margins: synthesis of Leg 81 results on the west margin of Rockall Plateau. In Roberts, D.G., Schnitker, D., et al., Init. Repts. DSDP, 81: Washington (U.S. Govt. Printing Office), 883911.

Schrader, E.L., and Stow, S.H., 1983. Geochemistry and mineralogy of fresh and altered basalts from the Galapagos rift. In Honnorez, J., Von Herzen, R.P., et al., Init. Repts. DSDP, 70: Washington (U.S. Govt. Printing Office), 391-408.

Spencer, K.J., and Lindsley, D.H., 1981. A solution model for coexisting iron titanium oxides. Am. Mineral., 66:1189-1201.

Thy, P., and Lofgren, G.E., 1994. Experimental constraints on the low-pressure evolution of transitional and mildly alkalic basalts: the effect of FeTi oxide minerals and the origin of basaltic andesites. Contrib. Mineral. Petrol., 116:340-351

Vierek, L.G., Hertogen, J., Parson, L.M., Morton, A.C., Love, D., and Gibson, I.L., 1989. Chemical stratigraphy and petrology of the Vøring Plateau tholeiitic lavas and interlayered volcaniclastic sediments at ODP Hole 642E. In Eldholm, O., Thiede, J., Taylor, E., et al., Proc. ODP, Sci. Results, 104: College Station, TX (Ocean Drilling Program), 367-396.

Wass, S.Y., 1973. The origin and petrogenetic significance of hour-glass zoning in titaniferous clinopyroxenes. Mineral. Mag., 39:133-144.

Wood, B.J., and Banno, S., 1973. Garnet-orthopyroxene and orthopyroxeneclinopyroxene relationships in simple and complex systems. Contrib. Mineral. Petrol., 42:109-124.

Date of initial receipt: 8 November 1995

Date of acceptance: 23 May 1996

Ms 152SR-232

Table 2. Representative analyses of olivine.

\begin{tabular}{|c|c|c|c|c|c|c|c|c|c|c|c|c|c|c|}
\hline Core, section: & $20 \mathrm{R}-4$ & $20 \mathrm{R}-4$ & $20 \mathrm{R}-4$ & $55 \mathrm{R}-4$ & $55 \mathrm{R}-4$ & $57 \mathrm{R}-3$ & $57 \mathrm{R}-3$ & $57 \mathrm{R}-3$ & $72 \mathrm{R}-1$ & $72 \mathrm{R}-1$ & 72R-1 & $88 \mathrm{R}-7$ & $88 \mathrm{R}-7$ & $88 \mathrm{R}-7$ \\
\hline Interval $(\mathrm{cm})$ : & $122-127$ & $122-127$ & $122-127$ & $10-11$ & $10-11$ & $85-86$ & $85-86$ & $85-86$ & $82-85$ & $82-85$ & $82-85$ & $83-86$ & $83-86$ & $83-86$ \\
\hline Unit: & $32 \mathrm{~B}$ & $32 \mathrm{~B}$ & $32 \mathrm{~B}$ & 60 & 60 & $61 \mathrm{~B}$ & $61 \mathrm{~B}$ & $61 \mathrm{~B}$ & $73 \mathrm{~A}$ & $73 \mathrm{~A}$ & $73 \mathrm{~A}$ & 84 & 84 & 84 \\
\hline $\mathrm{SiO}_{2}$ & 39.79 & 38.40 & 37.51 & 39.30 & 37.77 & 41.09 & 40.24 & 39.98 & 39.06 & 38.91 & 38.94 & 36.81 & 36.26 & 36.04 \\
\hline $\mathrm{Al}_{2} \mathrm{O}_{3}$ & 0.10 & 0.07 & 0.04 & 0.02 & 0.00 & 0.09 & 0.09 & 0.08 & 0.07 & 0.05 & 0.00 & 0.00 & 0.00 & 0.00 \\
\hline $\mathrm{FeOt}$ & 7.45 & 15.12 & 20.63 & 16.05 & 22.68 & 9.20 & 12.85 & 14.27 & 11.99 & 14.82 & 16.83 & 30.25 & 33.52 & 34.46 \\
\hline $\mathrm{MnO}$ & 0.13 & 0.22 & 0.37 & 0.24 & 0.32 & 0.12 & 0.22 & 0.18 & 0.22 & 0.22 & 0.21 & 0.50 & 0.46 & 0.59 \\
\hline $\mathrm{MgO}$ & 50.79 & 44.83 & 39.89 & 44.13 & 38.42 & 49.03 & 45.41 & 44.95 & 46.72 & 44.85 & 42.86 & 32.38 & 29.71 & 28.81 \\
\hline $\mathrm{CaO}$ & 0.23 & 0.22 & 0.26 & 0.34 & 0.33 & 0.29 & 0.30 & 0.29 & 0.31 & 0.31 & 0.36 & 0.23 & 0.19 & 0.24 \\
\hline $\mathrm{Cr}_{2} \mathrm{O}_{3}$ & 0.12 & 0.17 & 0.03 & 0.00 & 0.00 & 0.00 & 0.00 & 0.00 & 0.05 & 0.00 & 0.00 & 0.00 & 0.00 & 0.00 \\
\hline $\mathrm{NiO}$ & 0.45 & 0.35 & 0.20 & 0.00 & 0.00 & 0.33 & 0.29 & 0.20 & 0.55 & 0.00 & 0.00 & 0.00 & 0.00 & 0.00 \\
\hline Total & 99.05 & 99.39 & 98.93 & 100.07 & 99.52 & 100.15 & 99.39 & 99.95 & 98.96 & 99.16 & 99.19 & 100.17 & 100.13 & 100.14 \\
\hline Fo mol\% & 92.40 & 84.09 & 77.51 & 83.05 & 75.12 & 90.48 & 86.30 & 84.88 & 87.41 & 84.36 & 81.95 & 65.61 & 61.23 & 59.84 \\
\hline
\end{tabular}


Table 3. Representative analyses of chromian spinel.

\begin{tabular}{|c|c|c|c|c|c|}
\hline Core, section: & $18 \mathrm{R}-3$ & $18 \mathrm{R}-3$ & $20 \mathrm{R}-4$ & $57 \mathrm{R}-3$ & $72 \mathrm{R}-1$ \\
\hline Interval $(\mathrm{cm})$ : & $35-36$ & $35-36$ & $122-127$ & $85-86$ & $82-85$ \\
\hline Unit: & 25 & 25 & 32B & $61 B$ & $73 \mathrm{~A}$ \\
\hline $\mathrm{SiO}_{2}$ & 0.34 & 0.41 & 0.43 & 0.86 & 0.30 \\
\hline $\mathrm{TiO}_{2}^{2}$ & 1.19 & 0.66 & 0.45 & 1.12 & 0.74 \\
\hline $\mathrm{Al}_{2} \mathrm{O}_{3}$ & 19.81 & 28.80 & 20.58 & 24.13 & 21.37 \\
\hline $\mathrm{FeO}$ & 21.14 & 15.55 & 11.65 & 19.22 & 20.30 \\
\hline $\mathrm{Fe}_{2} \mathrm{O}_{3}$ & 10.19 & 11.67 & 4.76 & 8.06 & 10.92 \\
\hline $\mathrm{MnO}$ & 0.29 & 0.17 & 0.17 & 0.24 & 0.24 \\
\hline $\mathrm{MgO}$ & 9.35 & 13.64 & 15.25 & 10.94 & 9.75 \\
\hline $\mathrm{Cr}_{2} \mathrm{O}_{3}$ & 36.83 & 28.12 & 45.57 & 34.54 & 35.17 \\
\hline Total & 99.14 & 99.02 & 98.85 & 99.10 & 98.79 \\
\hline
\end{tabular}

Table 4. Representative analyses of plagioclase.

\begin{tabular}{|c|c|c|c|c|c|c|c|c|c|c|c|c|c|c|}
\hline Core, section: & $18 \mathrm{R}-3$ & $18 \mathrm{R}-3$ & $20 \mathrm{R}-4$ & $57 \mathrm{R}-3$ & $57 \mathrm{R}-3$ & $57 \mathrm{R}-3$ & $79 \mathrm{R}-2$ & $79 \mathrm{R}-2$ & $94 \mathrm{R}-1$ & 94R-1 & $94 \mathrm{R}-1$ & $94 \mathrm{R}-1$ & 94R-1 & $94 \mathrm{R}-1$ \\
\hline Interval $(\mathrm{cm})$ : & $35-36$ & $35-36$ & $122-127$ & $85-86$ & $85-86$ & $85-86$ & $64-67$ & $64-67$ & $71-74$ & $71-74$ & $71-74$ & $71-74$ & $71-74$ & $71-74$ \\
\hline Unit: & 25 & 25 & $32 \mathrm{~B}$ & $61 \mathrm{~B}$ & $61 \mathrm{~B}$ & $61 \mathrm{~B}$ & 78 & 78 & 87 & 87 & 87 & 87 & 87 & 87 \\
\hline $\mathrm{SiO}_{2}$ & 53.10 & 56.87 & 49.43 & 46.26 & 48.68 & 51.45 & 49.70 & 52.08 & 50.69 & 54.25 & 60.35 & 62.32 & 64.95 & 67.01 \\
\hline $\mathrm{Al}_{2} \mathrm{O}_{3}$ & 28.52 & 25.73 & 30.75 & 32.99 & 31.99 & 29.38 & 31.97 & 29.62 & 30.63 & 28.28 & 24.26 & 22.99 & 20.72 & 18.45 \\
\hline $\mathrm{FeO}$ & 1.00 & 0.72 & 0.96 & 0.57 & 0.57 & 0.50 & 0.50 & 0.73 & 0.79 & 0.87 & 0.69 & 0.47 & 0.69 & 0.68 \\
\hline $\mathrm{MgO}$ & 0.12 & 0.16 & 0.03 & 0.12 & 0.00 & 0.13 & 0.16 & 0.20 & 0.02 & 0.07 & & 0.00 & 0.02 & \\
\hline $\mathrm{CaO}$ & 12.45 & 9.45 & 15.25 & 17.46 & 15.70 & 13.42 & 15.76 & 13.33 & 14.09 & 11.06 & 6.24 & 4.42 & 2.28 & 0.48 \\
\hline $\mathrm{Na}_{2} \mathrm{O}$ & 4.18 & 6.05 & 2.91 & 1.53 & 2.50 & 3.85 & 2.56 & 3.81 & 3.57 & 5.12 & 7.41 & 8.27 & 8.26 & 7.99 \\
\hline $\mathrm{K}_{2} \mathrm{O}$ & 0.09 & 0.22 & 0.12 & 0.03 & 0.09 & 0.14 & 0.06 & 0.13 & 0.12 & 0.34 & 0.91 & 1.30 & 3.08 & 5.36 \\
\hline Total & 99.44 & 99.20 & 99.45 & 98.95 & 99.52 & 98.87 & 100.70 & 99.90 & 99.90 & 100.00 & 99.85 & 99.78 & 99.99 & 99.98 \\
\hline An $\operatorname{mol} \%$ & 61.89 & 45.73 & 73.84 & 86.19 & 77.26 & 65.25 & 77.05 & 65.41 & 68.14 & 53.36 & 30.09 & 21.10 & 10.91 & 2.26 \\
\hline Or mol\% & 0.54 & 1.27 & 0.67 & 0.17 & 0.50 & 0.83 & 0.34 & 0.75 & 0.66 & 1.95 & 5.22 & 7.41 & 17.55 & 29.91 \\
\hline Core, section: & $55 \mathrm{R}-4$ & $55 \mathrm{R}-4$ & $55 \mathrm{R}-4$ & $40 \mathrm{R}-4$ & $40 \mathrm{R}-4$ & $53 \mathrm{R}-1$ & 53R-1 & $47 \mathrm{R}-2$ & $47 R-2$ & $47 \mathrm{R}-2$ & $47 \mathrm{R}-2$ & $47 R-2$ & $47 \mathrm{R}-2$ & $47 \mathrm{R}-2$ \\
\hline Interval $(\mathrm{cm})$ : & $10-11$ & $10-11$ & $10-11$ & $78-81$ & $78-81$ & $77-78$ & $77-78$ & $70-72$ & $70-72$ & $70-72$ & $70-72$ & $70-72$ & $70-72$ & $70-72$ \\
\hline Unit: & 60 & 60 & 60 & 52 & 52 & 56 & 56 & 54 & 54 & 54 & 54 & 54 & 54 & 54 \\
\hline $\mathrm{SiO}_{2}$ & 45.82 & 49.01 & 52.23 & 52.04 & 55.26 & 57.67 & 64.00 & 47.16 & 50.59 & 53.54 & 56.42 & 60.58 & 61.66 & 64.66 \\
\hline $\mathrm{Al}_{2} \mathrm{O}_{3}$ & 33.83 & 30.64 & 29.11 & 29.64 & 27.43 & 24.99 & 20.94 & 33.32 & 30.76 & 28.39 & 27.11 & 23.54 & 23.35 & 20.74 \\
\hline $\mathrm{FeO}$ & 0.57 & 1.46 & 1.06 & 0.75 & 0.77 & 0.43 & 0.48 & 0.71 & 0.74 & 0.83 & 1.01 & 0.62 & 0.62 & 0.34 \\
\hline $\mathrm{MgO}$ & 0.03 & 0.53 & 0.04 & 0.00 & 0.03 & 0.00 & 0.00 & 0.07 & 0.05 & 0.08 & 0.00 & 0.00 & 0.02 & 0.00 \\
\hline $\mathrm{CaO}$ & 18.49 & 14.84 & 12.72 & 12.72 & 10.35 & 7.89 & 2.87 & 17.45 & 14.55 & 12.17 & 9.99 & 6.09 & 5.24 & 2.19 \\
\hline $\mathrm{Na}_{2} \mathrm{O}$ & 1.37 & 3.01 & 4.64 & 4.05 & 5.41 & 6.57 & 7.45 & 1.45 & 3.24 & 4.42 & 5.66 & 7.36 & 7.86 & 7.99 \\
\hline $\mathrm{K}_{2} \mathrm{O}$ & 0.02 & 0.14 & 0.24 & 0.29 & 0.49 & 0.92 & 3.47 & 0.01 & 0.09 & 0.30 & 0.50 & 1.01 & 1.14 & 3.34 \\
\hline Total & 100.13 & 99.62 & 100.04 & 99.49 & 99.73 & 98.47 & 99.20 & 100.19 & 100.02 & 99.73 & 100.69 & 99.20 & 99.89 & 99.27 \\
\hline An mol\% & 88.08 & 72.57 & 59.46 & 62.38 & 49.97 & 37.82 & 14.03 & 86.84 & 70.95 & 59.26 & 47.95 & 29.56 & 25.17 & 10.61 \\
\hline Or mol\% & 0.09 & 0.80 & 1.32 & 1.66 & 2.79 & 5.24 & 20.15 & 0.07 & 0.51 & 1.75 & 2.86 & 5.80 & 6.52 & 19.29 \\
\hline
\end{tabular}

Note: Analyses are ordered, as on Figure 4, following the petrographic evolution from picrites to more evolved basalts and dacites. 
Table 5. Representative analyses of pyroxenes.

\begin{tabular}{|c|c|c|c|c|c|c|c|c|c|c|c|c|c|c|}
\hline Core, section: & $18 \mathrm{R}-3$ & $18 \mathrm{R}-3$ & $20 \mathrm{R}-4$ & $20 \mathrm{R}-4$ & $57 \mathrm{R}-3$ & $57 \mathrm{R}-3$ & $79 \mathrm{R}-2$ & $79 \mathrm{R}-2$ & $88 \mathrm{R}-7$ & $88 \mathrm{R}-7$ & $88 \mathrm{R}-7$ & 94R-1 & 94R-1 & $94 \mathrm{R}-1$ \\
\hline Interval $(\mathrm{cm})$ : & $35-36$ & $35-36$ & $122-127$ & $122-127$ & $85-86$ & $85-86$ & $64-67$ & $64-67$ & $83-86$ & $83-86$ & $83-86$ & $71-74$ & $71-74$ & $71-74$ \\
\hline Unit: & 25 & 25 & $32 \mathrm{~B}$ & $32 \mathrm{~B}$ & $61 \mathrm{~B}$ & $61 B$ & 78 & 78 & 84 & 84 & 84 & 87 & 87 & 87 \\
\hline $\mathrm{SiO}_{2}$ & 49.34 & 50.22 & 51.62 & 50.15 & 49.54 & 49.90 & 50.56 & 50.00 & 52.35 & 51.03 & 52.49 & 50.71 & 50.32 & 52.40 \\
\hline $\mathrm{TiO}_{2}$ & 1.52 & 1.63 & 0.53 & 1.46 & 1.28 & 1.52 & 0.73 & 0.71 & 0.38 & 1.08 & 0.52 & 0.45 & 0.96 & 0.18 \\
\hline $\mathrm{Al}_{2} \mathrm{O}_{3}$ & 2.65 & 2.43 & 2.32 & 2.59 & 4.37 & 2.88 & 3.68 & 2.44 & 1.77 & 1.64 & 0.65 & 3.40 & 1.87 & 0.18 \\
\hline $\mathrm{FeO}$ & 11.12 & 13.11 & 7.52 & 8.90 & 7.35 & 11.21 & 8.29 & 12.32 & 6.44 & 11.80 & 19.56 & 6.12 & 11.00 & 23.16 \\
\hline $\mathrm{MnO}$ & 0.25 & 0.31 & 0.18 & 0.20 & 0.14 & 0.28 & 0.16 & 0.35 & 0.35 & 0.31 & 0.48 & 0.11 & 0.27 & 0.32 \\
\hline $\mathrm{MgO}$ & 14.21 & 13.26 & 16.88 & 15.75 & 14.10 & 13.71 & 14.53 & 14.07 & 16.77 & 15.70 & 20.52 & 15.56 & 14.98 & 21.67 \\
\hline $\mathrm{CaO}$ & 19.32 & 18.44 & 19.58 & 19.41 & 21.06 & 19.06 & 21.22 & 19.12 & 20.64 & 17.45 & 4.66 & 21.19 & 19.29 & 1.07 \\
\hline $\mathrm{Na}_{2} \mathrm{O}$ & 0.28 & 0.30 & 0.15 & 0.32 & 0.34 & 0.32 & 0.32 & 0.32 & 0.27 & 0.37 & 0.22 & 0.30 & 0.44 & 0.14 \\
\hline $\mathrm{Cr}_{2} \mathrm{O}_{3}$ & 0.15 & 0.03 & 0.29 & 0.24 & 0.60 & 0.04 & 0.08 & 0.01 & 0.42 & 0.00 & 0.00 & 1.26 & 0.00 & 0.00 \\
\hline Total & 98.84 & 99.73 & 99.08 & 99.01 & 98.78 & 98.90 & 99.58 & 99.32 & 99.39 & 99.37 & 99.09 & 99.10 & 99.12 & 99.13 \\
\hline En mol\% & 41.21 & 38.95 & 47.85 & 45.25 & 42.16 & 40.49 & 42.08 & 40.29 & 47.35 & 44.81 & 58.43 & 45.38 & 42.59 & 60.84 \\
\hline Fs mol\% & 18.51 & 22.12 & 12.25 & 14.67 & 12.57 & 19.05 & 13.74 & 20.36 & 10.76 & 19.40 & 32.03 & 10.20 & 17.98 & 37.00 \\
\hline Wo mol\% & 40.28 & 38.93 & 39.90 & 40.08 & 45.27 & 40.46 & 44.18 & 39.35 & 41.89 & 35.80 & 9.54 & 44.42 & 39.42 & 2.16 \\
\hline Core, section: & 90R-1 & 90R-1 & $90 \mathrm{R}-1$ & $55 \mathrm{R}-4$ & $55 \mathrm{R}-4$ & $40 \mathrm{R}-4$ & $40 \mathrm{R}-4$ & $40 \mathrm{R}-4$ & $40 \mathrm{R}-4$ & $23 \mathrm{R}-3$ & $47 \mathrm{R}-2$ & $47 \mathrm{R}-2$ & 53R-1 & \\
\hline Interval $(\mathrm{cm})$ : & $58-59$ & $58-59$ & $58-59$ & $10-11$ & $10-11$ & $78-81$ & $78-81$ & $78-81$ & $78-81$ & $10-13$ & $70-72$ & $70-72$ & $77-78$ & \\
\hline Unit: & 85 & 85 & 85 & 60 & 60 & 52 & 52 & 52 & 52 & $35 \mathrm{~B}$ & 54 & 54 & 56 & \\
\hline $\mathrm{SiO}_{2}$ & 52.24 & 50.92 & 51.57 & 50.49 & 47.96 & 51.32 & 50.67 & 50.96 & 51.38 & 50.78 & 52.03 & 51.11 & 49.83 & \\
\hline $\mathrm{TiO}_{2}^{2}$ & 0.17 & 0.29 & 0.35 & 0.27 & 0.84 & 0.35 & 0.32 & 0.53 & 0.50 & 0.28 & 0.35 & 0.42 & 0.34 & \\
\hline $\mathrm{Al}_{2} \mathrm{O}_{3}$ & 1.85 & 3.32 & 1.36 & 3.48 & 5.37 & 0.70 & 0.47 & 2.00 & 1.45 & 1.84 & 2.38 & 3.26 & 2.27 & \\
\hline $\mathrm{FeO}$ & 5.95 & 5.84 & 11.08 & 5.47 & 7.73 & 22.25 & 26.09 & 11.65 & 13.02 & 11.94 & 7.26 & 6.29 & 13.03 & \\
\hline $\mathrm{MnO}$ & 0.10 & 0.16 & 0.27 & 0.13 & 0.19 & 0.51 & 0.46 & 0.22 & 0.29 & 0.60 & 0.15 & 0.19 & 0.33 & \\
\hline $\mathrm{MgO}$ & 17.23 & 16.15 & 15.89 & 15.60 & 14.86 & 19.55 & 16.63 & 14.53 & 14.82 & 13.96 & 17.53 & 16.21 & 13.94 & \\
\hline $\mathrm{CaO}$ & 20.90 & 21.62 & 18.53 & 22.46 & 20.91 & 4.59 & 4.30 & 18.92 & 17.61 & 19.46 & 19.06 & 20.79 & 18.63 & \\
\hline $\mathrm{Na}_{2} \mathrm{O}$ & 0.22 & 0.28 & 0.19 & 0.30 & 0.32 & 0.10 & 0.09 & 0.28 & 0.26 & 0.36 & 0.21 & 0.24 & 0.53 & \\
\hline $\mathrm{Cr}_{2}^{2} \mathrm{O}_{3}$ & 0.62 & 0.95 & 0.04 & 1.04 & 0.70 & 0.00 & 0.01 & 0.00 & 0.00 & 0.00 & 0.19 & 0.58 & 0.02 & \\
\hline Total & 99.28 & 99.55 & 99.27 & 99.24 & 98.88 & 99.36 & 99.04 & 99.10 & 99.32 & 99.23 & 99.16 & 99.10 & 98.92 & \\
\hline En mol\% & 48.33 & 46.07 & 44.66 & 44.71 & 43.28 & 54.89 & 48.03 & 41.77 & 42.40 & 39.90 & 49.53 & 46.59 & 40.02 & \\
\hline Fs mol\% & 9.52 & 9.61 & 17.90 & 9.01 & 12.95 & 35.85 & 43.03 & 19.14 & 21.38 & 20.12 & 11.75 & 10.45 & 21.53 & \\
\hline Wo mol\% & 42.14 & 44.33 & 37.44 & 46.28 & 43.78 & 9.25 & 8.94 & 39.09 & 36.23 & 39.98 & 38.71 & 42.95 & 38.45 & \\
\hline
\end{tabular}

Note: Analyses are ordered, as in Figure 5, following the petrographic evolution from picrites to more evolved basalts and dacites.

Table 6. Representative analyses of ilmenites and titanomagnetites.

\begin{tabular}{|c|c|c|c|c|c|c|c|c|c|c|c|}
\hline \multirow{4}{*}{$\begin{array}{l}\text { Core, section: } \\
\text { Interval }(\mathrm{cm}) \text { : } \\
\text { Unit: }\end{array}$} & \multicolumn{4}{|c|}{ Ilmenites } & \multicolumn{7}{|c|}{ Titanomagnetites } \\
\hline & $57 \mathrm{R}-3$ & $88 \mathrm{R}-7$ & $94 \mathrm{R}-1$ & $67 \mathrm{R}-3$ & $57 \mathrm{R}-3$ & $72 \mathrm{R}-1$ & $79 \mathrm{R}-2$ & 94R-1 & $55 \mathrm{R}-4$ & $40 \mathrm{R}-4$ & $23 R-3$ \\
\hline & $85-86$ & $83-86$ & $71-74$ & $130-132$ & $85-86$ & $82-85$ & $64-67$ & $71-74$ & $10-11$ & $78-81$ & $10-13$ \\
\hline & $61 \mathrm{~B}$ & 84 & 87 & 70 & $61 \mathrm{~B}$ & $73 \mathrm{~A}$ & 78 & 87 & 60 & 52 & $35 \mathrm{~B}$ \\
\hline $\mathrm{SiO}_{2}$ & 0.74 & 0.17 & 0.15 & 0.26 & 1.00 & 0.37 & 0.39 & 0.22 & 0.19 & 0.31 & 0.33 \\
\hline $\mathrm{TiO}_{2}$ & 50.64 & 48.65 & 47.46 & 49.51 & 0.79 & 25.70 & 19.27 & 12.53 & 21.22 & 24.23 & 14.06 \\
\hline $\mathrm{Al}_{2} \mathrm{O}_{3}$ & 0.06 & 0.12 & 0.12 & 0.04 & 48.37 & 1.55 & 1.62 & 1.30 & 1.67 & 1.97 & 1.67 \\
\hline $\mathrm{FeO}$ & 41.42 & 37.07 & 35.63 & 41.27 & 25.05 & 51.91 & 46.41 & 39.42 & 45.93 & 48.51 & 40.12 \\
\hline $\mathrm{Fe}_{2} \mathrm{O}_{3}$ & 4.97 & 9.19 & 11.52 & 5.89 & 0.48 & 16.11 & 28.01 & 42.29 & 25.44 & 18.22 & 38.40 \\
\hline $\mathrm{MnO}$ & 0.50 & 0.38 & 0.42 & 0.43 & 0.50 & 0.50 & 0.65 & 0.34 & 0.44 & 3.20 & 0.76 \\
\hline $\mathrm{MgO}$ & 2.04 & 3.58 & 3.76 & 1.60 & 21.09 & 1.21 & 0.74 & 1.55 & 2.76 & 0.81 & 1.59 \\
\hline $\mathrm{Cr}_{2} \mathrm{O}_{3}$ & 0.00 & 0.00 & 0.00 & 0.00 & 0.00 & 0.04 & 0.00 & 0.12 & 1.10 & 0.06 & 0.00 \\
\hline Total & 100.37 & 99.15 & 99.06 & 99.00 & 97.28 & 97.39 & 97.08 & 97.77 & 98.75 & 97.30 & 96.93 \\
\hline
\end{tabular}

Table 7. Representative analyses of glasses.

\begin{tabular}{lccrrr}
\hline Core, section: & $11 \mathrm{R}-2$ & $45 \mathrm{R}-1$ & $47 \mathrm{R}-2$ & $53 \mathrm{R}-1$ & $79 \mathrm{R}-2$ \\
Interval $(\mathrm{cm}):$ & $124-128$ & $55-59$ & $70-72$ & $77-78$ & $64-67$ \\
Unit: & 13 & 53 & 54 & 56 & 78 \\
\hline $\mathrm{SiO}_{2}$ & 50.46 & 55.44 & 68.69 & 64.88 & 50.76 \\
$\mathrm{TiO}_{2}$ & 0.33 & 0.48 & 0.18 & 0.68 & 0.27 \\
$\mathrm{Al}_{2} \mathrm{O}_{3}$ & 15.76 & 16.04 & 16.32 & 13.62 & 14.55 \\
$\mathrm{FeOt}$ & 8.26 & 4.56 & 1.55 & 7.19 & 7.92 \\
$\mathrm{MnO}$ & 0.17 & 0.03 & 0.06 & 0.45 & 0.11 \\
$\mathrm{MgO}$ & 10.75 & 1.24 & 0.03 & 0.29 & 9.93 \\
$\mathrm{CaO}$ & 1.52 & 3.83 & 0.29 & 1.98 & 3.32 \\
$\mathrm{Na}{ }_{2} \mathrm{O}$ & 4.74 & 5.28 & 5.02 & 4.14 & 4.54 \\
$\mathrm{~K}_{2} \mathrm{O}$ & 0.52 & 3.10 & 7.72 & 5.37 & 0.48 \\
$\mathrm{Total}$ & 92.50 & 90.00 & 99.86 & 98.59 & 91.88 \\
\hline
\end{tabular}

